\title{
Concejos rurales y aspectos de gestión en la tierra de Piedrahíta (siglo XV)
}

\section{Rural communities and management issues in the jurisdiction of Piedrahíta (fifteenth century)}

\author{
Laura DA GRACA \\ Universidad de La Plata-Universidad de Buenos Aires \\ lauradagraca@gmail.com
}

Recibido: $31 / 10 / 2014$

Aceptado: 26/02/2015

\section{RESUMEN}

Se analiza el grado de autonomía de los concejos rurales del término de Piedrahíta desde una doble perspectiva: la gestión del espacio jurisdiccional por parte del centro urbano (recaudación de tributos, control de comunales, distribución de funciones coercitivas y de justicia) y la actuación de las autoridades aldeanas a nivel local. Se plantea que la autonomía relativa de los concejos rurales es una aspiración central de la comunidad política aldeana y un rasgo asociado a un perfil de gestión que tiende a delegar la administración interna de la jurisdicción en oficiales de bajo rango y en los canales organizativos fundados en la participación de pecheros. Esta modalidad de gestión favorece el avance de las economías de los líderes aldeanos y la difusión de prácticas contrarias al interés comunitario.

Palabras clave: Concejos rurales, Gestión, Autogobierno aldeano, Autoridades urbanas y rurales, Piedrahíta, Siglo XV.

\begin{abstract}
The degree of autonomy of the village councils in the municipal district of Piedrahita is analysed from a twofold perspective: the management of the territory by urban authorities (i.e. tax collection, control over common resources, distribution of coercive tasks and justice) and the performance of village authorities at the local level. It is posited that the relative autonomy of the village councils is a core aspiration of the local political community, as well as a feature of a management scheme that tends to delegate the administration of the jurisdiction to lower-ranking officials and to a tax collection system based on peasant involvement. This form of management favours the village leaders' economies and breeds practices that go against the common interest.
\end{abstract}

Key words: Rural communities, Management, Village self-government, Urban and local authorities, Fifteenth-century Piedrahíta.

Sumario: 1. Introducción. 2. La relación del centro urbano con los concejos rurales en la comunidad de villa y tierra de Piedrahíta. 2.1. Recaudación de tributos y oficiales subalternos. 2.2. Testimonios de visitas de las autoridades urbanas a las aldeas. 3. Autogobierno y elite dirigente en el concejo rural 
de Navarredonda. 3.1. El concejo rural y la autonomía aldeana. 3.2. Prácticas agrarias de los oficiales aldeanos: la difusión de cerrados. 4. Conclusiones.

\section{INTRODUCCIÓN}

La comunidad rural como forma institucional es un fenómeno que los historiadores han vinculado a una fase de evolución del feudalismo, con argumentos diversos y evidencia de variaciones regionales respecto a los orígenes, antecedentes, funcionalidad y grados de autonomía de la organización aldeana ${ }^{1}$. En este marco, algunos autores han planteado que las instituciones aldeanas responden a la necesidad de gestión por parte del señor, que utiliza en su provecho las formas organizativas preexistentes y otorga nuevas funciones que refuerzan la autoridad de los líderes aldeanos, de entre los cuales se reclutarán agentes de recaudación de rentas y oficiales para los tribunales locales ${ }^{2}$. Se ha sugerido también que la aceptación del sistema se apoya en esta forma de articulación, mediante la cual el señor delega en la comunidad campesina funciones coercitivas y reconoce a las instituciones locales la capacidad de regular sus propios asuntos ${ }^{3}$. Christopher Dyer es un exponente de esta perspectiva, que plantea para el caso inglés; los rasgos más salientes de la comunidad rural se resumen en su relativa autonomía respecto de la autoridad superior, su funcionalidad para la gestión señorial -aspectos vinculados al desinterés por parte del señor en los asuntos agrarios y a su imposibilidad de ejercer un control efectivo sobre dominios de grandes extensiones-, y en el desarrollo creciente de diferenciaciones internas, que se manifiesta en el control del gobierno aldeano por una elite con capacidad de imponer su interés particular y en el avance de cercamientos sobre el arable en la Baja Edad Media ${ }^{4}$. El autor formula esta caracterización en oposición a los enfoques que tienden a idealizar la comunidad rural como entidad cohesionada por una identidad de intereses; Dyer también quiere destacar el protagonismo aldeano frente a los enfoques que postulan la desaparición del campesinado y de sus formas sociales como condición del cambio.

Este tipo de aproximación a la comunidad rural no es habitual en los estudios sobre concejos castellanos. Si bien los historiadores constatan la estratificación social

1 Wickham, Community and Clientele, p. 4; una síntesis de los distintos argumentos en p. 229; un panorama de las variantes históricas europeas en cap. 8. Expone y analiza críticamente un conjunto de explicaciones Astarita, Revolución en el burgo, vol. I, cap. 4. El autor considera variantes según la dinámica específica de las distintas clases estamentales y otros factores que inciden sobre la conveniencia de favorecer el autogobierno local; enfatiza también factores endógenos, Ibidem, vol. II, cap. 12.

2 DYer, "The English Medieval Village Community"; también "The ineffectiveness of Lordship"; BourIN, "Peasant Elites and Village Communities", pp. 108-109; Morsel, La aristocracia medieval, p. 229. Sobre el recurso a tributarios para tareas de gestión, en referencia a Inglaterra, WickHAm, Community and Clientele, p. 205, y en relación al área concejil AstaRITA, "Representación política de los tributarios", pp. 143-145. Menciona la preferencia por parte del poder superior por esta modalidad de gestión de la renta MonsALvo ANTÓN, "Transformaciones sociales y relaciones de poder", p. 158.

3 Astarita, “'Tuvo conciencia de clase el campesino medieval?”, pp. 111-112; WiCKHAM, "Conclusions”; DYer, "Power and conflict".

4 DYer, "Power and conflict". Sobre las funciones y rasgos centrales de la comunidad rural Dyer, Lords and peasants in a changing society, pp. 355-372. 
de las comunidades y la participación de pecheros en la gestión del sistema no han jerarquizado estos problemas. Por otro lado, se han producido pocas investigaciones específicas sobre el ámbito aldeano; el concejo rural se ha abordado en clave descriptiva, aisladamente de su inserción en un sistema político ${ }^{5}$, o ha sido objeto de análisis desde la perspectiva de la apropiación de términos por parte de otros sectores y de la transformación del sistema agrario ${ }^{6}$. La extensión del fenómeno de usurpación del espacio comunal ha estimulado estudios de carácter más general, cuyo objeto es la actuación del conjunto de pecheros y de sus representantes, a quienes se atribuye un ideario legalista opuesto a la violencia de los privilegiados; esta opinión se basa en el desempeño o el discurso de figuras notorias que trascienden los marcos aldeanos ${ }^{7}$. En esta perspectiva, que ha desarrollado Monsalvo Antón, el concejo rural se presenta como la pieza menos ilustre de una estructura organizativa pechera que en sus distintas instancias (aldea/ sexmos/ cuadrillas y collaciones/ conjunto de villa y tierra) mantiene vigente la práctica asamblearia, una forma de actuación política alternativa frente al monopolio de los oficios municipales por parte de la oligarquía urbana ${ }^{8}$. El autor distingue también el interés de la Tierra en su conjunto del de las aldeas singulares, que defendieron la gestión autónoma de sus comunales en oposición a un derecho comunal generalizado 9 . El interés por la conflictividad entre estamentos ha estimulado también la evaluación de la participación política de pecheros en la estructura concejil o el acceso a puestos de poder en el gobierno municipa ${ }^{10}$. Frente a estos problemas -cuyo estudio privilegia la presencia de oficiales pecheros en instancias de decisión claves o la acción política a escala supralocal- el papel de sectores tributarios en la administración cotidiana del espacio señorial y en la regulación de la vida aldeana se considera un aspecto poco relevante ${ }^{11}$. Correlativamente, la relación del núcleo urbano con el espacio rural se contempla mayormente en términos de antagonismo y subordinación ${ }^{12}$, o bien se asume una visión instrumental según la cual

5 Por ejemplo Clemente Ramos, “Ordenanzas y conflictividad intracampesina en Mengabril”, o SÁNCHEZ Benito, "Estructura social de un pueblo de Castilla".

6 Monsalvo Antón, "Paisaje agrario" (este trabajo, de gran interés, ha sido reeditado en Monsalvo AnTón, Comunalismo concejil abulense, donde el autor reúne un conjunto de artículos relacionados con la problemática del comunal). Presenta un caso inverso (la transformación de una dehesa privada en aldea) Clemente Ramos, "Valdetorres".

7 Monsalvo Antón, "Ideario sociopolítico"; "Costumbres y comunales"; también "Paisaje agrario"; aquí el autor distingue la actuación de los procuradores generales del papel más deslucido de las autoridades rurales (p. 105).

8 Monsalvo Antón, "Ayuntados a concejo".

9 Monsalvo Antón, "Raíces sociales de los valores estamentales concejiles", p. 368; "Espacios de pastoreo de la tierra de Ávila”, pp. 241-249. Lo mismo sugiere García Garcimartín, Articulación jurisdiccional, p. 616.

10 Monsalvo Antón, "La participación política”; JARA Fuente, "Sobre el concejo cerrado", entre otros.

11 Por ejemplo Monsalvo Antón, El sistema político concejil, p. 244. Incluso cuando se describe el funcionamiento concejil en relación a las aldeas la atención se concentra en la figura del procurador general de pecheros. Ver por ejemplo Moreno NúÑEz, Ávila y su tierra en la Baja Edad Media, pp. 145-147, o DiAGO Hernando, "Introducción a la historia institucional del concejo de Soria", pp. 34 y ss.

12 Por ejemplo Clemente Ramos y Rodríguez Grajera, "Plasencia y su tierra”, pp. 734-736. Olmos Herguedas, La comunidad de villa y tierra de Cuéllar, p. 173 propone que se trata de una relación de "tensión permanente". 
el sistema concejil sirve a los intereses de la elite privilegiada ${ }^{13}$, sin considerar que esta modalidad de gobierno pudo favorecer el desarrollo de procesos acumulativos aldeanos ${ }^{14}$.

En este estudio se propone que la autonomía relativa de los concejos rurales, que se verifica en el área concejil (es decir, en concejos de realengo y de señorío privado del sur del Duero) ${ }^{15}$, es un rasgo asociado a un perfil de gestión que tiende a delegar la administración interna de la jurisdicción en oficiales de bajo rango y en los canales organizativos fundados en la participación de pecheros, de los cuales depende la eficacia del sistema para la reproducción social. La actuación autónoma de los concejos rurales, una aspiración de la comunidad política aldeana, favorece el avance de las economías de los líderes locales y el despliegue de prácticas contrarias al interés comunitario.

Analizaremos la situación de los concejos aldeanos en el ámbito de Piedrahíta, concejo de titularidad privada segregado de Ávila. ${ }^{16}$ Enfocaremos el problema desde la gestión del conjunto por parte del centro urbano y desde el interior de un concejo rural. Examinaremos el modo en que se concreta la articulación del centro urbano con las aldeas de la jurisdicción, atendiendo a la supervisión del ámbito rural por parte de las autoridades urbanas y a la distribución de funciones de gestión y de justicia en términos normativos y prácticos. La participación de pecheros en los mecanismos de gobierno parece asociarse al perfil de las autoridades urbanas, cuya actuación política se concentra en la defensa de la jurisdicción y del interés sectorial del concejo urbano, evidenciándose un muy escaso y poco efectivo control sobre el ámbito rural subordinado. La delegación por parte del señor de funciones coercitivas en instancias intermedias se replica en la actuación del patriciado, que delega aspectos administrativos y coactivos en sectores subalternos; el autogobierno aldeano podría verse como el último componente de esta forma de gestión. Al respecto analizaremos la actuación de las autoridades locales en uno de los concejos rurales del ámbito de Piedrahíta, Navarredonda, donde se puede observar la manifestación práctica de la autonomía aldeana y una operatoria orientada a la privatización del espacio agrario por parte de procuradores, sexmeros y oficiales aldeanos.

${ }^{13}$ Es el balance historiográfico de Martín Cea y BonachíA, "Oligarquías y poderes concejiles", p. 33.

${ }^{14}$ Sobre el enriquecimiento de sectores aldeanos Asenjo GonZÁlez, Segovia, pp. 490-497.

15 Sobre el grado desigual de injerencia señorial y sus efectos sobre la evolución de las comunidades en la Baja Edad Media DA Graca, Poder político y dinámica feudal; sobre el carácter no universal de la organización de comunas y comunidades AsTARITA, Revolución en el burgo.

${ }^{16}$ Sobre los señoríos surgidos en el espacio abulense durante los siglos XIV y XV MoReno NúÑEz, Ávila y su tierra en la Baja Edad Media, pp. 107-125; sobre el de Valdecorneja, al cual pertenece Piedrahíta, pp. 109111, también Luis López, La Comunidad de villa y tierra de Piedrahita, pp. 45-49 y 153-156, y la introducción del autor al volumen I de la Documentación medieval de Piedrahita (LuIs LóPEz, Documentación medieval de Piedrahita, vol. I, Estudio, pp. 15-39). 


\section{LA RELACIÓN DEL CENTRO URBANO CON LOS CONCEJOS RURALES EN LA COMUNIDAD DE VILLA Y TIERRA DE PIEDRAHÍTA}

Dentro del ámbito concejil, Piedrahíta se considera un concejo mediano; abarca más de $600 \mathrm{~km} 2$ y hacia mediados del siglo XV, según surge de los repartimientos de rentas, comprende catorce concejos rurales (Navaescurial, Aldehuela, Santiago, Hoyorredondo, Horcajo, Zapardiel, Navalperal, Navacepeda, Hoyos y Hoyos, Navarredonda, San Martín del Pimpollar, San Martín de la Vega, La Garganta del Villar y San Miguel de Corneja) identificados como sexmos o cuartos y agrupados como "los cuartos y la Sierra" o "La Sierra y Lo Llano"; cada uno de estos concejos rurales comprende varias aldeas ${ }^{17}$. El concejo de Piedrahíta se encuentra a su vez integrado en el señorío de Valdecorneja, que incluye otras cuatro villas con su tierra (El Barco de Ávila, El Mirón, La Horcajada y Bohoyo) y limita con los concejos de Bonilla de la Sierra, Villatoro, Villafranca, Ávila, Arenas de San Pedro, Candeleda y Mombeltrán. Analizaremos la relación del centro urbano con los concejos rurales en base a la información proveniente del archivo municipal de Piedrahíta ${ }^{18}$ y del archivo de Navarredonda de Gredos, principal concejo rural de la comarca de La Sierra y el único sobre el cual contamos con documentación local, referida al periodo $1450-1491^{19}$.

El detalle de los libros de cuentas del concejo de Piedrahíta permite observar cómo se concretaba en la práctica el control sobre las aldeas. Los balances informan los gastos en viáticos que originan los desplazamientos a las aldeas, quiénes los realizan y por qué motivos, de lo cual se puede obtener un panorama de los contactos entre ciudad y tierra desde el punto de vista de la gestión.

\subsection{RECAUDACIÓN DE TRIBUTOS Y OFICIALES SUBALTERNOS}

Según los balances de cuentas disponibles sobre el periodo de los años 1434 a 1480 el vínculo del centro urbano con las aldeas se manifiesta principalmente en el envío regular de notificaciones a los concejos rurales para que sus representantes concurran a los repartimientos de rentas, que se realizan en Piedrahíta. Los concejos rurales son convocados a los repartimientos de yantar y chapines, pedido y monedas, servicio

17 El concejo de Piedrahíta ha sido estudiado minuciosamente por Carmelo Luis López. Para aspectos específicos debe consultarse Luis López, La Comunidad de villa y tierra de Piedrahíta. También puede verse De Santos Canalejo, "Piedrahíta". Sobre la evolución del alfoz de Piedrahíta y las distintas subdivisiones Luis López, La comunidad de villa y tierra de Piedrahita, pp. 153-172; sobre las aldeas comprendidas en los concejos rurales hasta 1444, p. 168; también LuIs LóPEz, Documentación medieval de Piedrahita, vol. I, Estudio, pp. 43-54. Una síntesis sobre la evolución de la jurisdicción de Piedrahíta puede verse en MonsALvo ANTón, "La participación política", p. 69 nota 80. El autor destaca el poderío de los concejos rurales de Piedrahíta, a los que califica de "macroconcejos".

18 Luis López, Colección Documental del Archivo Municipal de Piedrahíta; Luis López, Documentación medieval de Piedrahíta, vol. I; Del Ser Quijano, Documentación medieval de Piedrahita, vol. II; LuIS LóPEZ, Documentación medieval de Piedrahita, vol. III; Del SER QuiJano, Las finanzas de un concejo castellano, vol. II; Luis LóPez, Las finanzas de un concejo castellano, vol. III; Monsalvo Antón, Las finanzas de un concejo castellano, vol. IV; Tena García, Las finanzas de un concejo castellano, vol. V; Beltrán SuÁrez, Las finanzas de un concejo castellano, vol. VI; Álvarez Fernández, Las finanzas de un concejo castellano, vol. VII.

19 Del Ser Quijano, Documentación Medieval en Archivos Municipales Abulenses. Documentación Medieval del Archivo Municipal de Navarredonda de Gredos, doc. 1. 
y montazgo y alcabala del $\operatorname{pan}^{20}$. La presencia de representantes aldeanos se requiere también para distribuir obligaciones ocasionales como la de aportar veladores o ballesteros ${ }^{21}$, y se recurre a la reunión de autoridades concejiles y representantes pecheros de los cuatro concejos del señorío de Valdecorneja para abordar el reparto de pedidos extraordinarios y para tratar temas específicos ${ }^{22}$. Este sistema, que participa de la gestión de la renta a las autoridades aldeanas, resulta en principio eficaz; se comprueba que los sexmeros concurrían a los repartimientos, los cuales raramente mencionan tributos adeudados ${ }^{23}$. Tampoco hay en los balances de cuentas mayor evidencia de conflicto en relación al pago de rentas concejiles, recaudadas mediante arrendamientos. Los testimonios de insubordinación, en cambio, se concentran en las obligaciones recaudadas de manera informal, como el presente del señor, un tributo de composición diversa exigido regularmente y asociado también a eventos ocasionales (bodas, nacimientos, etc.) y a visitas imprevistas del señor. El incumplimiento reiterado de este tipo de contribución pone en evidencia, por un lado, que la aceptación del vínculo de explotación es relativa, o en todo caso limitada a un conjunto de obligaciones estables ${ }^{24}$, y por otro, la centralidad de los canales organizativos formales del sistema concejil, por fuera de los cuales la extracción del excedente no puede concretarse de manera regular. Los libros de cuentas atestiguan las dificultades para lograr que los concejos rurales contribuyan al aprovisionamiento de la despensa señorial: en 1436 se notifica a los alcaldes de la tierra que serán prendados porque no han entregado las perdices del presente del señor ${ }^{25}$, situación que se repite en $1440^{26}$; en 1443 se exceptúa a los concejos de La Sierra ${ }^{27}$, lo que podría interpretarse como

${ }^{20}$ Para detalles sobre los sistemas de reparto de los tributos que recoge la documentación de Piedrahíta, procedimientos de recaudación y cantidades pagadas en los concejos de Valdecorneja DeL SER QUIJANO, "Fiscalidad real y señorial", y en Piedrahíta Luis LóPez, La Comunidad de villa y tierra de Piedrahíta, pp. 184-209, o bien Luis LóPEz, Documentación medieval de Piedrahíta, vol. I, Estudio, pp. 62-74.

21 Por ejemplo, "Mandó, el alcayde e rregidores, que se allegasen çiertos labradores e el procurador e Alfonso Sánchez, escrivano e Pedro Gonçalez a fazer el padrón e el rrepartimiento de las armas de vallestas e coraças", TENA GARCíA, Las finanzas de un concejo castellano, vol. V, p. 196.

22 La convocatoria a "juntas" aparece regularmente en los libros de cuentas. El mayordomo de 1462 resume el carácter de estas reuniones: "Et con lo que se gastó en la yantar de las yuntas que fezieron la justiçia e rregidores e pecheros e seysmeros de La Sierra en Los Palaçios, quando las villas todas se juntaron allí sobre dar orden en las tasas que entonçes vinieron del rrey, nuestro señor", Ibidem, p. 37.

${ }^{23}$ Los repartimientos son el contenido principal de la Documentación medieval de Piedrahíta, vol. I, II y III. La presencia de sexmeros se consigna regularmente. Se anotan también las ausencias ocasionales, como en el caso de los sexmeros de La Sierra que no pudieron concurrir al repartimiento de 1463 por las condiciones climáticas, LuIs LóPEz, Documentación medieval de Piedrahíta, vol. III, doc. 65

${ }^{24}$ Significativamente, en el repartimiento de yantar y chapines de 1462 se reparten también "las costas del proçeso que los buenos onbres pecheros fezieron sobre los diezmos, que les levavan demás de lo que avían de pagar de derecho", Ibidem, doc. 20.

25 Del Ser Quijano, Las finanzas de un concejo castellano, vol. II, p. 48.

26 "Di a Estevan, pregonero, dos maravedís, porque fue a los quartos a prendar los alcaldes por las perdizes", Ibidem, p. 109; "fueron a prendar a los alcaldes de los quartos, porque non tenían las perdizes", Ibidem, p. 113.

27 "Mas di a Benito Sánchez, pregonero, diez maravedís, porque levó una carta a los conçejos de La Sierra, que non truxesen el presente de las bodas de la fija del conde (...) Más di otra vez al dicho Benito Sánchez, pregonero, diez maravedís por mandado de Juan Martínez de Tamayo, porque levó otra vez otra carta a los conçejos de La Sierra, que non truxesen el dicho presente", Ibidem, p. 198. 
la condonación eventual de un tributo resistido. El rechazo a las contribuciones en especie se observa también en otras comarcas: en 1447 el concejo envía cartas "sobre el vino que non querían levar los del quarto de Santiago"28; el mismo año se consigna que este concejo y el de Aldehuela "no traýan las perdizes"29. En 1455 se incluyen en el repartimiento de otras rentas los productos del presente, para los cuales en su momento "non ovo dineros" 30 .

Probablemente a raíz del reiterado incumplimiento de estas obligaciones por parte de los concejos rurales, los regidores ordenan al mayordomo requerir los productos personalmente ${ }^{31}$, aunque la medida no resulta efectiva: en 1460 el concejo tiene que enviar un hombre a La Sierra "a façer execuçión de los quesos, que non truxeron al castillo"32; en 1462, el mayordomo y el alguacil deben dividirse la tarea de ir a prendar porque los cuartos de Navaescurial, Santiago y Aldehuela no llevaron los pollos y terneras del presente del señor ${ }^{33}$. En 1464 se procede al reparto formal de esta obligación; a diferencia de los repartimientos regulares, en éste se establecen penas y se acuerda que para la entrega "llamen un buen omne de Navarredonda e otro de Navaçepeda e otro de Santiago y otro de Navalescorial" ${ }^{34}$. Estas medidas reflejan el carácter conflictivo del tributo, que se intenta mitigar con la intervención de representantes aldeanos en el circuito de recaudación. En 1465 el mayordomo recorre la comarca para recaudar el dinero de la renta de la cerca, de la cual es arrendador, y de paso "esecutar en los conçejos" 35; el mismo año los concejos rurales envían decir al mayordomo "si quería gallinas, que perdizes que non las podían aver"36. Los balances de 1470,1471 y 1473 sugieren que los concejos rurales siguen faltando a esta obliga-

${ }^{28}$ Luis López, Las finanzas de un concejo castellano, vol. III, p. 144.

${ }^{29}$ Ibidem, p. 145.

30 "Se ayuntaron a tasar e derramar (...) mill et ochoçientos maravedís para pagar seys terneras que se avían conprado para el serviçio de la señora, Doña María, que se avían echado en el otro rrepartimiento antes deste et non ovo dineros para se pagar; et más que se devían de otra ternera çinquenta maravedís", DEL SER Quijano, Documentación medieval de Piedrahíta, vol. II, doc. 91 (1455); el repartimiento anterior Ibidem, doc. 90 .

31 “Que gasté yo, el dicho Lope Garçía, mayordomo, quando me mandaron yr los señores rregidores a La Sierra a fazer traher las perdizes e gallinas”, Monsalvo AnTón, Las finanzas de un concejo castellano, vol. IV, p. 62.

32 Ibidem, p. 192.

33 "Fuy yo, el dicho mayordomo, e un onbre del alguazil al quarto de Navaescorial a prendar por las pollas e terneras del serviçio del conde", TenA GARcía, Las finanzas de un concejo castellano, vol. V, p. 41; "fue el alguazil, con un mandamiento del alcayde e alcalldes e rregidores, a prendar al quarto de Santiago e del Aldehuela, porque non traxeron la ternera e los pollos para el presente del señor", Ibidem, p. 42.

34 Luis López, Documentación medieval de Piedrahita, vol. III, doc. 85.

35 "Más fui yo a La Sierra a rrecabdar los dineros de la çerca e llevé a Juan de Bonilla conmigo, para esecutar en los conçejos. Estuve allá diez e seys días", TenA GARCíA, Las finanzas de un concejo castellano, vol. V, p. 179.

36 Ibidem, p. 193. Una ordenanza posterior vincula esta circunstancia a la práctica de la recatonía: "Por cabsa que algunas personas, vezinos desas dichas mis villas e sus tierras, que conpran perdizes e truchas para las tornar a vender por vía de recatonía fuera de ellas e de sus tierras, non se pueden aver ningunas al tiempo que yo las he menester", Luis LóPez, Colección Documental del Archivo Municipal de Piedrahita, doc. 99 (1513). 
ción ${ }^{37}$. En 1476 el pregonero es enviado al cuarto de Hoyorredondo "a prendar por las perdizes del conde"; $; 8$ en 1477 el mayordomo envía a requerir gallinas para el señor ${ }^{39}$, con las que éste no contará durante su visita, ya que al año siguiente se notifica a la tierra "para que traxesen las gallinas del presente que se devían para el duque, nuestro señor, quando vyno"

La informalidad respecto a la modalidad de recaudación de este tributo redunda en un mayor protagonismo del mayordomo de concejo en la gestión de la renta. En 1478 , ante el rumor de la cercanía del duque, el mayordomo se anticipa y requiere perdices a las aldeas, sin esperar notificaciones formales de autoridades superiores ${ }^{41}$. El ejemplo demuestra la interiorización por parte de los oficiales de menor rango de las funciones coercitivas delegadas por el señor en el concejo urbano, que también se manifiesta en la dedicación servil a las tareas de gestión. Esta actitud probablemente haya sido la condición principal para el desempeño del oficio, el cual no parece asociarse a una cualificación técnica: el mayordomo de 1473, un sastre, lleva consigo un mozo que escribe por él ${ }^{42}$, y el de 1476, carpintero, aclara que no sabe leer ${ }^{43}$. Los regidores, a su vez, se valen de la debilidad de un oficial que no proviene del estrato privilegiado, ordenándole las tareas más penosas, como desplazarse personalmente a las aldeas para requerir tributos de bajo nivel de cumplimiento. El traslado a las aldeas más alejadas, que el mayordomo realiza solo o en compañía de un mozo, supone alrededor de una semana entre viaje y estadía, y ésta puede prolongarse por la inclemencia del clima de la zona: el mayordomo del año 1455, a quien se le ordena requerir a las aldeas los productos del presente, queda en La Sierra veintitrés días a causa de la nieve ${ }^{44}$; el de 1479 , que se ocupa de recaudar la renta de la cerca -para lo cual debe realizar tres viajes anuales de seis días cada uno- reclama sin éxito más dinero en concepto de viáticos ${ }^{45}$. Enviar notificaciones a los concejos más alejados no

37 Beltrán SuÁrez, Las finanzas de un concejo castellano, vol. VI, p. 110. "Gasté para las perdizes d'este presente año, mill maravedís". Al margen: "Deve las perdizes", Ibidem, p. 136; "Más, enbié un onbre a Bonilla e Villafranca a buscar perdizes, para si pudiera complir con el mayordomo del duque, nuestro señor". Al margen: "A la tierra", Ibidem, p. 203.

38 Álvarez FernáNDEZ, Las finanzas de un concejo castellano, vol. VII, p. 86.

39 Ibidem, p. 124.

40 Ibidem, p. 145.

41 "Di a los pregoneros por que fuesen a la Syerra e Llano a fazer que traxesen perdizes, porque dezían que venía el duque aquí, sesenta maravedís, lo qual dixo rrabý Mayr”, Ibidem, p. 136.

42 "Que fue a coger el terçio a La Sierra (...) e asý mesmo a rrecabdar dineros de yantar e chapines con un rroçín en que yo yva e un moço que me escriviese las cuentas", BELTRÁN SuÁrez, Las finanzas de un concejo castellano, vol. VI, p. 196.

43 "Fuy a La Sierra a rrecabdar el terçio primero de la çerca e tardé allá quatro dýas, a XXV maravedís, yo e un moço, porque yo non sabía leer", Állvarez Fernández, Las finanzas de un concejo castellano, vol. VII, p. 94.

44 “Que gasté yo, el dicho Lope Garçia, mayordomo, quando me mandaron yr los señores rregidores a La Sierra a fazer traher las perdizes e gallinas, que estude detenido con las muchas nieves veynte e tres días. Gasté ochenta maravedís", Monsalvo AnTón, Las finanzas de un concejo castellano, vol. IV, p. 62.

45 "Que fuy a coger el terçio primero de La Syerra; estude allá seys días y, para el terçio segundo, otros seys días y en el postrimero otros seys días. Asý que son diez e ocho días, en que montan, a veynte e çinco maravedís cada día, quatroçientos e çinquenta maravedís. Lo que merezco más dexo a vertud e nobleza de los señores", y escrito al margen: "Esto mandaron lo señores rregidores. Que non se le cuenten a él nin a ningund mayordomo, que de aquí adelante fuere, salvo a veynte maravedís cada un día, como estava ordenado. Asý 
es una rutina mecánica: el mayordomo de 1465 ofrece a un hombre casi el doble del dinero acostumbrado para que lleve una carta a La Sierra "porque fazía mal tienpo e non fallava quien fuese allá" ${ }^{4}$. La dificultad que implicaba el desplazamiento a las aldeas se evidencia en el hecho de que el pregonero es uno de los pocos oficiales que percibe un aguinaldo, lo cual sugiere cierta consideración por la tarea que realiza ${ }^{47}$.

El perfil modesto de los mayordomos se deduce de los gastos que cargan al concejo. Lope García, tejedor, anota 27 maravedíes en concepto de zapatos para su mozo y herraduras para la mula ${ }^{48}$, lo que también atestigua con qué medios ha trajinado por las aldeas. En 1463 notifica gastos ocasionados por imprevistos: por una desinteligencia en la entrega del presente Lope García debe mantener y alimentar ochenta gallinas en su casa durante tres días ${ }^{49}$; en 1465 se le ordena hospedar y brindar cuidados médicos a un aldeano que cayó de una torre ${ }^{50}$. Una de sus obligaciones regulares es comprar besugos para los regidores. Las molestias que se toma Lope García ilustran la posición del mayordomo, tratado a la vez como subordinado incondicional y epicentro de la vida concejil. Los regidores, por su parte, no siempre le comunican los motivos de los gastos que ocasionan al concejo, lo que reafirma la segregación de este oficial con respecto a la oligarquía urbana: según anota el mayordomo de 1445 los regidores enviaron dinero al alcalde "ençeladamente" ${ }^{\text {; }}$; el de 1462 debe destinar más de mil maravedíes del presupuesto para cubrir los gastos de un viaje de las autoridades cuyos motivos ignora ${ }^{52}$; el de 1455 advierte, respecto a una orden de pago a ciertos sujetos, que "non dize para qué" 53 ; en referencia a un viaje de dos regidores a Mengamuñoz el mayordomo de 1475 escribe: "ellos vos den cuenta qué fizieron allá" ${ }^{4}$. La exclusión del mayordomo de ciertos asuntos del concejo define también el perfil del oficial que más directamente encarna el nexo entre el concejo urbano y las aldeas.

La dedicación del mayordomo contrasta con el desdén de los regidores hacia las actividades del concejo. Una ordenanza establece descuentos en el salario de los que no concurran a las reuniones del consistorio ${ }^{55}$; la ineficacia de esta medida motiva una disposición que eleva la pena a dos reales ${ }^{56}$; otra norma se refiere en su encabeza-

\footnotetext{
que non se le cargan salvo trezientos e sesenta maravedís", Álvarez Fernández, Las finanzas de un concejo castellano, vol. VII, p. 169.

46 Tena García, Las finanzas de un concejo castellano, vol. V, p. 194.

47 Ibidem, p. 75.

48 Ibidem, p. 199.

49 "Costaron quarenta pares de gallinas $240 \mathrm{~m} \mathrm{(...)} \mathrm{Estudieron} \mathrm{tres} \mathrm{días} \mathrm{las} \mathrm{gallinas} \mathrm{en} \mathrm{casa,} \mathrm{que} \mathrm{non} \mathrm{se}$ dieron. Diles tres çelemines de trigo", Ibidem, p. 105.

50 "Más mandó, el alcayde e alcalldes e rregidores, quando cayó el onbre de Foyorredondo de la torre, mandaron que le traxiese a mi casa e que le diese lo que oviese menester. Gasté en xaropes e melizinas e en gallinas çien maravedís", Ibidem, p. 105.

51 LuIs López, Las finanzas de un concejo castellano, vol. III, p. 61.

52 Tena García, Las finanzas de un concejo castellano, vol. V, p. 57.

53 Monsalvo Antón, Las finanzas de un concejo castellano, vol. IV, p. 26.

54 Álvarez Fernández, Las finanzas de un concejo castellano, vol. VII, p. 56.

55 Luis López, Colección Documental del Archivo Municipal de Piedrahíta, doc. 77.

56 Ibidem, doc. 138.
} 
miento a "la negligençia de los regidores", que no visitan las cárceles ${ }^{57}$. El absentismo de los regidores es un rasgo conocido; lo han detectado los historiadores en diversos concejos $^{58}$. El desinterés por la rutina burocrática, o la tensión entre este aspecto de la función de gobierno y la aspiración a un posicionamiento jerarquizado por parte de los regidores explica su tendencia a delegar tareas de gestión en oficiales subalternos. En otros concejos estos oficiales pertenecen al "segmento modesto" del estamento privilegiado, opuesto al patriciado ${ }^{59}$; en nuestro caso el desplazamiento de funciones administrativas y de coacción se extiende a sectores excluidos del privilegio y a los propios aldeanos, que son reclutados para actuar en otros lugares, como veremos luego, o convocados como recaudadores aun cuando dilatan la entrega del tributo o "recavdan los maravedíes... e después los gastan en sus neçesidades e faziendas" Los alguaciles y recaudadores aldeanos están capacitados para prendar ${ }^{61}$, y a ellos deben dirigirse las autoridades urbanas para identificar a los que no han pagado ${ }^{62}$. Con respecto a esta tarea, se prohíbe ejecutar a los deudores cuando éstos concurren al mercado, lo que sugiere que los alguaciles también evitaban desplazarse hasta las aldeas $^{63}$.

A mediados del siglo XV muchos de los oficiales urbanos son pecheros. Entre los sujetos a quienes se identifica como labradores en el control de cuentas de 1467 figura Alonso Fernández de los Caños el viejo, probablemente padre del mayordomo de ese año, Alonso Fernández de los Caños el $\mathrm{mozo}^{64}$, de lo cual se deduce la condición de este último, que comparte con mayordomos de otros años, cuyo bajo perfil hemos establecido. Sin dudas es pechero Lope García, mayordomo durante casi una década, al igual que el procurador de concejo y el escribano que lo acompañan en su gestión, ya que reclaman y consiguen la exención de obligaciones de hospedaje "por ser ofiçiales", salvo "en aquellos tienpos que los libres non pueden ser escusados" Entre los que controlan las cuentas encontramos también un escribano "por los buenos onbres pecheros" ${ }^{\prime 66}$. La presencia de pecheros en los repartimientos y en el control

57 Ibidem, doc. 46.

58 Ofrecen datos precisos sobre la baja asistencia de los regidores a las reuniones concejiles SÁNCHEZ BENITo, "El poder en una pequeña ciudad castellana", pp. 200-201 y MorENo NúÑEz, Ávila y su tierra en la Baja Edad Media, pp. 169-174. Lo mismo demuestran Monsalvo Antón, El sistema político concejil, pp. 229-231, y Diago Hernando, "Cambios políticos", p. 310. Jara Fuente atribuye el absentismo de los regidores en Cuenca a la cohesión del grupo, que haría innecesario que concurran todos, y a la poca relevancia de las reuniones, JARA FuENTE, "Sobre el concejo cerrado", p. 118.

59 Monsalvo Antón, "Torres, tierras, linajes”, p. 196.

${ }^{60}$ Luis LóPez, Colección Documental del Archivo Municipal de Piedrahíta, doc. 70, p. 158.

61 "Otrosý ordenaron los buenos onbres que tienen cargo del conçejo con los alcaldes de este año de LXVI años por autoridad de la carta e ordenança del conde (...) que coxedor ninguno del pueblo nin alguazil nin otro prendador ninguno que sea del concejo que no sea osado a prendar buey de ninguno que sea, oviendo otros bienes en que puede fazer la tal prenda", Del Ser Quijano, Documentación Medieval en Archivos Municipales Abulenses. Documentación Medieval del Archivo Municipal de Navarredonda de Gredos, doc. 1, 76 (p. 212 ).

${ }^{62}$ Luis López, Colección Documental del Archivo Municipal de Piedrahíta, doc. 67.

${ }^{63}$ Luis López, Documentación medieval de Piedrahita, vol. I, doc. 35 (1433).

${ }^{64}$ Beltrán SuÁrez, Las finanzas de un concejo castellano, vol. VI, p. 78.

${ }^{65}$ Luis López, Documentación medieval de Piedrahita, vol. III, doc. 89 y 109.

${ }^{66}$ Álvarez Fernández, Las finanzas de un concejo castellano, vol. VII, p. 131. 
de cuentas, que se constata en los balances, se establece como obligatoria en 1494, a pedido de los procuradores ${ }^{67}$.

Aunque las autoridades concejiles deploran el hecho de que muchos oficios, entre ellos los de fiel, "andan abatydos en personas comunes" ${ }^{68}$, éstas resultan más confiables para las tareas de gestión, al menos a los ojos del mayordomo de 1471, que con respecto al arrendamiento de la renta del río anota al margen: "nunca más se dé a escudero esta rrenta" 69 . Hay arrendadores que provienen de las aldeas, como los que tienen a cargo la renta de la cerca en 1441, residentes en Navarredonda ${ }^{70}$. También es vecino de Navarredonda el alcalde de la Mesta de 1467, Alonso Sánchez de los Pinos ${ }^{71}$. Pedro Sánchez, escribano de concejo, proviene de Hoyos de Miguel Muñoz, aldea del concejo rural de San Martín del Pimpollar, y allí prefiere mantener la residencia, lo que ocasiona un trastorno a las autoridades urbanas, que deben enviar al pregonero cuando requieren sus servicios ${ }^{72}$. En 1439 se lo conmina, mediante carta del señor de Valdecorneja, a residir en la ciudad si desea mantener el oficio ${ }^{73}$. Sus servicios, no obstante, debieron ser muy valorados, ya que se desempeña en el puesto durante más de veinte años ${ }^{74}$.

Se deduce la importancia del estamento pechero en la gestión del espacio concejil, lo que también se comprueba cuando observamos las dificultades que plantea al concejo la recaudación de tributos no sujetos a los procedimientos formales basados en la participación de representantes aldeanos.

Por último, fuera de las notificaciones relativas a repartimientos de rentas y ejecuciones por falta de pago, el centro urbano toma contacto con las aldeas para obtener toros de lidia para las festividades anuales. Los vecinos a quienes el concejo compra toros pertenecen a la elite de las aldeas, según se deduce de la posición que ostentan

67 Luis López, Colección Documental del Archivo Municipal de Piedrahíta, doc. 50 (1494).

68 "e los fieladgos, que solian ser dados a los más honrrados de la dicha villa, e, agora, señor, andan abatydos en personas comunes, e en ellos es grand parte del regimiento de la dicha villa", Ibidem, doc. 17 (1464).

69 Beltrán SuÁrez, Las finanzas de un concejo castellano, vol. VI, p. 132.

70 “Otro alvalá de los rregidores, que libraron en los arrendadores de Navarredonda de la çerca a Andrés González e a sus compañeros de la dicha Navarredonda”, Del Ser QuiJano, Documentación medieval de Piedrahita, vol. II, p. 154.

71 El cargo de alcalde de la Mesta se crea en 1428 (LuIs López, Colección Documental del Archivo Municipal de Piedrahita, doc. 5). Alonso Sánchez de los Pinos actúa como tal en 1467, Del Ser QuiJano, Documentación Medieval en Archivos Municipales Abulenses. Documentación Medieval del Archivo Municipal de Navarredonda de Gredos, doc. 1, 26 (p. 203).

72 "Di a Benito, pregonero, otros çinco maravedís, quando fue a levar una carta de Ferrand Álvarez a llamar a Pero Sánchez, escrivano, a los Foyos de Miguelmuñoz”, Del SER Quijano, Las finanzas de un concejo castellano, vol. II, p. 59 (1437); “di a Benito, pregonero, por mandado del corregidor diez maravedís, porque fue a llamar a Pero Sánchez, escrivano, a su aldea", Ibidem, p. 63.

73 "Yo, Fernand Álvarez de Toledo, señor de Valdecorneja, vos fago saber que por parte del conçejo e rregidores de la dicha mi villa me fue dicho cónmo vos no estávades residente a servir vuestro ofiçio de la escrivanía. En lo qual diz que viene daño al conçejo (...) Por que vos mando que, del día questa mi carta viéredes, en treynta días, vengades a servir el dicho ofiçio, e lo continuedes. E que, sy ansý non lo fezyéredes, por esta carta mando a los rregidores de la dicha mi villa que provean del dicho ofiçio a persona que ellos entiendan que es pertenesçiente e cumpla mi serviçio e provea el dicho conçejo", LuIs LópEz, Documentación medieval de Piedrahita, vol. I, doc. 65 (1439).

74 Ibidem, doc. 27 (1419) y 100 (1447). 
en las transacciones ${ }^{75} \mathrm{y}$ de los oficios que desempeñan aquellos a quienes podemos identificar, como el caso de Alonso Martínez de Barajas, sexmero por Navarredonda, o el de Alonso Sánchez de los Pinos, alcalde de la Mesta con residencia en esta misma aldea $^{76}$.

\subsection{TESTIMONIOS DE VISITAS DE LAS AUTORIDADES URBANAS A LAS ALDEAS}

Además de garantizar el pago del tributo y la diversión del señor y los pobladores en el día de San Juan y otras fiestas, el concejo urbano debe supervisar el cumplimiento de la normativa general en las aldeas, para lo cual éstas deben ser visitadas regularmente. Las visitas dejan sus huellas en los libros de cuentas debido al gasto que suponen en concepto de viáticos para los oficiales. De acuerdo a la información de los balances del concejo de los años 1434 a 1480, los regidores visitan las aldeas muy esporádicamente; en cambio, suelen movilizarse a los concejos del señorío de Valdecorneja y a otros centros concejiles vecinos, como Villatoro, Bonilla de la Sierra o Mombeltrán, donde celebran reuniones entre pares o con poderes superiores en representación de Piedrahíta ${ }^{77}$. El control interno de la propia jurisdicción raramente aparece en la agenda concejil. Veamos los testimonios de visitas a las aldeas y otros indicios de actuación por parte del concejo urbano frente a irregularidades en la tierra, sin olvidar que la jurisdicción de Piedrahíta comprende en el período catorce concejos rurales, que abarcan a su vez varias aldeas.

Entre 1434 y 1444 la evidencia de actuación de las autoridades ante anomalías en las aldeas se limita a una carta que emplaza al concejo rural de San Martín de la Vega a restituir una tierra concejil ${ }^{78}$ y a una pesquisa sobre los pinares de San Martín del Pimpollar que se encomienda a un recaudador, probablemente aprovechando sus desplazamientos por la comarca ${ }^{79}$. El único registro de traslados de los regidores a la tierra es un viaje de carácter ineludible pues lo motiva el hecho de que los lugares

75 "Que di a dos peones, que fueron ayudar a traher el toro de Pedro Loçano a La Syerra, sesenta maravedís, que fue ansý la condiçión”, Álvarez FernÁNDEZ, Las finanzas de un concejo castellano, vol. VII, p. 139; “conpré otro toro (...) de Pedro Gómez del Barrio por mill e quatroçientos maravedís forros de alcavala; e yo non ge los quería dar e mandávale traher Martín Fernández". Al margen: "Toro de Santa María de agosto d'este año y byen caro", Beltrán SuÁrez, Las finanzas de un concejo castellano, vol. VI, p. 64.

76 Monsalvo Antón, Las finanzas de un concejo castellano, vol. IV, p. 101, 119 y 173.

77 Por ejemplo, "fue Fernando de Valdenebro a negoçiar çiertas cosas del conçejo con el señor duque al Varco", Álvarez Fernández, Las finanzas de un concejo castellano, vol. VII, p. 193; "fueron a Bonilla (...) a estar con el señor obispo, sobre las cosas e casos de la clerezía de la Yglesia d'esta villa”, Ibidem, p. 201; “Alonso Gonçalez de Armenteros, rregidor, que fue a Béjar sobre lo del alférez", Ibidem, p. 101; "fue al Colmenar sobre que avían entrado con gente armada en término de Piedrafita, tras el conde de Coria", Ibidem, p. 37; “di a Pedro de Várzena (...) porque fue a Bonilla, otra vez, a traher conclusyón sobre sy se alçaría el entredicho, e dixo que non", Ibidem, p. 68; "fueron sobre el debate de La Cabeçuela, e otros conçiertos de los corregidores con las villas de Piedrafita e el Barco", Del SER Quijano, Las finanzas de un concejo castellano, vol. II, p. 47, etc. Sobre las relaciones del concejo de Piedrahíta con los concejos limítrofes LuIs LóPEz, La Comunidad de villa y tierra de Piedrahita, pp. 130-150.

78 Del Ser Quijano, Las finanzas de un concejo castellano, vol. II, p. 60.

79 Ibidem, p. 252 y 272. 
del entonces sexmo de Caballeruelos quieren dividirse ${ }^{80}$. No hay noticias de controles en la tierra hasta 1445, año en que se menciona una pesquisa a La Sierra "sobre las rroturas" "1 ; cinco años después los regidores viajan a La Garganta del Villar "a derribar la casa que aý se faze" ${ }^{82}$, lo que tal vez alude a las edificaciones de un cercamiento. Al año siguiente se menciona un viaje a Hoyos del Espino que parece responder a un pedido de la propia aldea, ya que los taberneros del lugar solventan los viáticos de los regidores ${ }^{83}$.

Los libros de cuentas informan sobre una investigación relevante en el concejo de La Garganta del Villar en 1455 "sobre los mojones que se mudaron" y "sobre las derroturas" $" 84$, a lo cual siguen tres años sin datos de pesquisas a las aldeas. La investigación más importante que se registra en la documentación disponible, a juzgar por el gasto que ocasiona (700 maravedíes), el tiempo que lleva (17 días) y sobre todo por su reflejo en la documentación local, se lleva a cabo en 1458. Se trata de una pesquisa en La Sierra sobre "las rroturas que teníen tomados los conçejos e prados e otras cosas", que realizan tres regidores ${ }^{85}$. Esta pesquisa debió concentrarse en Navarredonda, ya que en el cuaderno del lugar se registran 18 entradas correspondientes a tierras que recupera el concejo rural en el año $1458^{86}$. Volveremos luego sobre esta pesquisa desde la perspectiva de Navarredonda.

El siguiente dato relativo a una investigación es una mención en las cuentas de 1462 a gastos en papel "sobre los alijares". Esta pesquisa incluye una convocatoria a los concejos de Aldehuela, Santiago, Hoyorredondo y Navaescurial para que acompañen a los regidores a Navarredonda, lo que evidencia que éstos reclutan refuerzos en otras aldeas para llevar a cabo operativos de cierta envergadura ${ }^{87}$. El mismo año las autoridades se reúnen con los regidores de la villa vecina de El Mirón a tratar sobre ciertos agravios relativos a términos que dicen sufrir los "buenos onbres" de Hoyorredondo, que concurren a la reunión ${ }^{88}$.

La siguiente pesquisa de importancia, semejante a la de 1458 por su duración y costo, se realiza en 1463, y se concentra en el concejo de La Garganta del Villar, al cual se le ordena "no sembrar las derroturas", lo que sugiere que los aldeanos han tomado tierras de los comunales para labranza ${ }^{89}$. Dos años después las autoridades

80 "Más, se gastó, quando fueron Sancho Gonçález e Rodrigálvarez e Ferrand Martínez, alcalde, e Alonso Sánchez, escribano, a estar con los conçejos de Aldihuela, quando andavan en debate por se fazer dos conçejos (...) çinquenta e tres maravedís", Ibidem, p. 198.

${ }^{81}$ Luis López, Las finanzas de un concejo castellano, vol. III, p. 64.

82 Ibidem, p. 165.

83 “Que tomaron Ferrand Martínez e Pedro Guerra en La Sierra, de Juan Gonçalez e de Andrés Gonçalez, taverneros de Los Hoyos del Espino, çinquenta maravedíes para gastar, quando fueron sobre los rrobos que fazían Pedro de Ávila e don Ferrand, segund paresçe por su alvalá”, Ibidem, p. 201.

${ }^{84}$ Monsalvo Antón, Las finanzas de un concejo castellano, vol. IV, p. 58.

85 Ibidem, p. 142.

86 Del Ser Quijano, Documentación Medieval en Archivos Municipales Abulenses. Documentación Medieval del Archivo Municipal de Navarredonda de Gredos, doc. 1, 28, 29, 30, 31, 32, 33, 34, 35, 36, 37, 38, 39, 40, 41, 42, 43, 44, 45 (pp. 204-205).

87 Tena García, Las finanzas de un concejo castellano, vol. V, p. 43.

88 Ibidem, p. 29.

89 Ibidem, p. 105-106, 206. 
se dirigen al concejo rural de Navaescurial, lindero al término de la villa de Piedrahíta, a definir los límites de la dehesa de Navacavera, uno de los bienes de propios de la comunidad de villa y tierra de Piedrahíta ${ }^{90}$. De acuerdo a la ordenanza que al respecto emite el concejo, se trata de sustraer a los aldeanos derechos colectivos, ya que el monte se acota "para los que biven en el cuerpo de la villa, e non para otros", estableciendo penas para "los de otra parte" que fueran a cortar leña ${ }^{91}$. El interés en consolidar una fuente de ingresos para el municipio justifica la movilización de alcaldes, regidores, escribanos, procuradores, labradores, y aun del mayordomo, que debe trasladarse al lugar a cocinar para todo el grupo ${ }^{92}$. La tarea no llega a concluirse y los regidores vuelven al lugar, ocasionando nuevos gastos en viáticos y en bebida para "çiertos labradores que andudieron con ellos" dentemente no les preocupa la suerte de los de Navaescurial, tal vez provienen del concejo rural de Hoyorredondo, ya que un vecino de este lugar aparece como testigo en la ordenanza relativa al caso.

El mismo año las autoridades se dirigen al concejo rural de Santiago, también limítrofe con la villa de Piedrahíta, a amojonar los montes y "desfazer los çerrados"; podría tratarse, en este caso, de una pesquisa relacionada con el avance de cercamientos, aunque el móvil parece asociarse nuevamente al ingreso derivado de multas y bienes de propios, ya que según la anotación del mayordomo habrían ido "por cabsa de la leña d'esta dicha villa". El viaje involucra a tres regidores, el alcalde, el escribano, el procurador y tres labradores ${ }^{94}$. Esta nutrida comitiva podría explicarse, al igual que en el caso anterior, por la localización de los concejos, ambos a poca distancia de Piedrahíta; así parece sugerirlo el hecho de que el mismo año, para prendar en el alejado concejo de Navalperal, las autoridades envíen al pregonero. Los que estaban en falta, esta vez, "avían conprado los bienes de los que se avían ido del señorío"95, contraviniendo una ordenanza dictada por el concejo unos meses antes ${ }^{96}$.

En las cuentas de 1467 no hay datos de visitas a las aldeas; faltan los balances de 1468, aunque en el de 1469 se mencionan ciertas prendas tomadas el año anterior a "los de Navarredonda", concejo rural que se perfila entre los de mayor protagonismo ${ }^{97}$. Según el libro de 1470 el único gasto ocasionado por controles en la tierra es una pesquisa al lugar de Navacepeda por ciertas "vacas estranjeras" que llevó a los alijares un sujeto a quien se le incautan cinco animales, de lo cual se notifica a los

90 Ibidem, p. 191. Sobre los bienes de la comunidad de villa y tierra de Piedrahíta LuIs LóPEZ, La Comunidad de villa y tierra de Piedrahita, pp. 176-181; sobre el caso de esta dehesa, apropiada por el concejo urbano, pp. 290-291.

91 Luis LóPez, Colección Documental del Archivo Municipal de Piedrahíta, doc. 20 (1465).

92 "Más acordaron, el alcayde e alcalldes e rregidores, que fuesen a mojonar los montes de las faldas de Navacabera al quarto de Navaescurial. E mandaron que les fuese a guisar de comer para ellos e para los escrivanos e procurador e para los labradores", TENA GARCíA, Las finanzas de un concejo castellano, vol. V, p. 191.

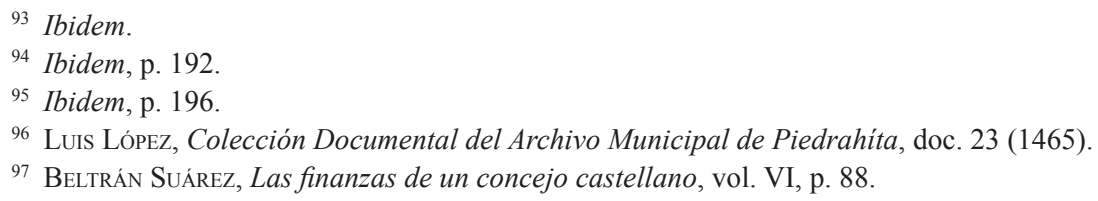


concejos de La Sierra, tal vez interesados en este problema ${ }^{98}$. En el balance de 1471 se menciona una deuda del concejo rural de Navarredonda "por çiertos pinos que furtaron"99, probablemente en pinares concejiles de Piedrahíta, de cuyo goce están excluidos los concejos rurales que poseen pinares propios ${ }^{100}$. El alcalde de Piedrahíta, Martín Fernández Godoy, se dirige ese año a las aldeas a redistribuir términos ${ }^{101}$. Estos viajes se aprovechan para el desempeño de otras funciones públicas en los lugares visitados, según puede verse en el cuaderno de Navarredonda, donde encontramos a Fernández Godoy confirmando ese año ordenanzas del concejo rural ${ }^{102}$. El hecho corrobora el carácter ocasional de la presencia de autoridades urbanas en las aldeas; sólo la pesquisa de 1458 y este viaje del alcalde en 1471 han dejado huellas en un documento que contiene información de los años 1450 a 1491.

No hay en los balances otros datos de visitas a la tierra en 1471; en cambio, el concejo urbano interviene frente a disputas que involucran otras jurisdicciones, como el conflicto entre el concejo rural de La Garganta del Villar y el señorío de Villato$\mathrm{ro}^{103}$, o el de los lugares de la comarca de La Sierra con las villas vecinas de Arenas de San Pedro y Mombeltrán ${ }^{104}$. En el balance de 1472 no hay datos sobre visitas a las aldeas. Las cuentas de 1473 registran en cambio bastante actividad. Las autoridades han tenido que viajar a la villa vecina de Bonilla de la Sierra a negociar con el obispo de Ávila, señor del lugar, de quien obtienen la absolución para los moradores de La Garganta del Villar, que habían sido excomulgados por derribar "unas çerradas", probablemente de vecinos de Bonilla con posesiones en el lugar ${ }^{105}$. El mismo año los regidores se dirigen a la zona de Hoyorredondo para "apear e ver las rrecovas que fazía el rrío"106, a la comarca de La Sierra para llevar a cabo una pesquisa "sobre la

98 Ibidem, p. 103, 104, 105, 120.

99 Ibidem, p. 132 y 156.

100 El concejo regula la concesión de permisos "a qualquier que oviere menester madera para fazer casas (...) salvo a Sant Martín del Pinpollar e a Navarredonda e a los Foyos del Espino e del Collado, por quanto tienen pinares dehesas de suyo", Luis López, Colección Documental del Archivo Municipal de Piedrahíta, doc. 2 (1405), p. 26.

101 "Más di por otra foja de gasto, firmada por los rregidores, de lo que se gastó de los que fueron a ygualar las pasturas con Martín Fernández de Godoy, el dicho año, trezientos e doze maravedís", BeLtráN SuÁREZ, Las finanzas de un concejo castellano, vol. VI, p. 138.

102 "Yo, Martín Fernández Godoy, alcalde de la villa de Piedrafita por mi señor el conde don Garçia, vi estas ordenanças quel conçejo, alcaldes e buenos onbres de Navarredonda fizieron e ordenaron, e de su pedimiento, la confirmo e apruevo", Del Ser Quijano, Documentación Medieval en Archivos Municipales Abulenses. Documentación Medieval del Archivo Municipal de Navarredonda de Gredos, doc. 1, 53 (1471) (p. 207).

103 “Di (...) a Gonçalo Gonçalez, por mandado de los rregidores, por que fuese a Villatoro sobre el devate de los de La Garganta del Villar”, Beltrán SuÁrez, Las finanzas de un concejo castellano, vol. VI, p. 140.

104 Ibidem, pp.141-142.

105 “Que dí por libramiento a Pedro de Várzena, rregidor, ochenta maravedís, porque fue a Bonilla a negoçiar con el señor obispo sobre la entrada de Guzmán en esta villa. Dos vezes que fue a Bonilla; e otros quarenta maravedís de una carta yñibitoria del señor obispo para el juez de Ávila con la absoluyçión de los de La Garganta de Villar que estavan escomulgados porque batieron unas çerradas", Ibidem, p. 180.

106 Ibidem, p. 181. 
saca del pan"107, y a otro lugar de la tierra para investigar ciertos pinares que habrían sido quemados ${ }^{108}$.

Según el balance del año 1474 el único traslado de los regidores a las aldeas por motivos de gestión se debe a un conflicto entre los lugares de Santiago, Aldehuela y Avellaneda con la villa vecina de El Barco ${ }^{109}$, lo cual confirma que las autoridades urbanas se movilizan preferentemente para misiones políticas exteriores al concejo. En 1475 los regidores realizan una pesquisa en La Sierra relacionada con los pinares $^{110}$, y en 1476 el alguacil investiga en esta comarca usurpaciones de comunales ${ }^{11}$. La situación debió desbordarlo, puesto que ya iniciada la pesquisa se ordena a los de Hoyorredondo y Aldehuela que acudan a La Sierra a acompañar a los oficiales urbanos $^{112}$. Tal vez las medidas del caso requieren de ciertos apoyos, para lo cual las autoridades reclutan personal de otras aldeas -en este caso, cercanas a la villa de Piedrahíta y alejadas de la zona del conflicto.

La siguiente visita de autoridades urbanas a las aldeas se produce cuatro años después a raíz de un problema de términos entre el concejo rural de La Garganta del Villar y el señorío vecino de Villatoro ${ }^{113}$; nuevamente una disputa entre jurisdicciones ha motivado la intervención concejil.

A diferencia de los viáticos del mayordomo o los mensajeros, las visitas de las autoridades a las aldeas representan importantes gastos en comidas, cuya composición se detalla en las cuentas del concejo. A pedido de los procuradores, se legisla sobre la cantidad de comida y bebida que pueden requerir los regidores de las aldeas cuando fueran a cumplir tareas de gestión, dado que se les paga para ello un salario ${ }^{114}$. Se deduce que la práctica del banquete, que remite al desplazamiento señorial antes que a la rutina burocrática, se percibía como un aspecto central de las visitas, lo que a su vez pone en duda la efectividad de estas últimas como instrumento de control. Esto se confirma en otra disposición que prohíbe a los que estuvieran siendo investigados ofrecer "dádivas y presentes" 115 , un recurso al que también apelan las autoridades; la sofisticación del menú de las reuniones políticas depende del potencial conflictivo del problema a tratar: los representantes de la tierra que en 1475 se movilizan a Piedrahíta con motivo de la intromisión de oficiales urbanos en el arrendamiento de las alcabalas son recibidos con pan, vino y queso, la colación habitual para labradores ${ }^{116}$; los que van el mismo año a denunciar agravios de los oficiales urbanos contra moradores

107 Ibidem, p. 208.

108 Ibidem, p. 198.

109 Álvarez Fernández, Las finanzas de un concejo castellano, vol. VII, p. 47.

110 Ibidem, p. 72.

111 "Di a Fernand Martínez de Cáçeres e a Rodrigo de Medina dozientos maravedís e más una pierna de carnero, quando fueron a La Sierra a ver los pinares e a fazer pesquisa de las tierras que estavan tomadas de los alixares", Ibidem, p. 89.

112 "Di más al pregonero çinco maravedís, porque fue a levar una carta del corregidor e rregidores a los de Foyorredondo y del Aldehuela, para que fuesen a La Syerra a estar con Fernando Martínez y Rrodrigo de Medina, sobre las rroturas", Ibidem, p. 89.

113 Ibidem, p. 204.

114 Luis LóPez, Colección Documental del Archivo Municipal de Piedrahíta, doc. 50.

115 Ibidem, doc. 50 y 51.

116 Álvarez Fernández, Las finanzas de un concejo castellano, vol. VII, p. 64 
de las aldeas y a advertir que por este motivo la tierra se estaría despoblando son agasajados además de lo básico con una preparación de huevos, asaduras, pescado, sardinas adobadas y de postre higos y peras con miel ${ }^{117}$. El testimonio de la importancia que dan las autoridades urbanas a esta denuncia es la inclusión en la agenda concejil de una visita a las aldeas para "saber los vasallos que se yva e quántos eran e para fablar con ellos para los sygurar e saber qué synrrazones les eran fechas para los remediar" ${ }^{\prime 18}$. La preocupación por resguardar el volumen de renta explica el intento de contentar a los procuradores con un yantar casi tan bueno como el que reciben los regidores del concejo vecino de Arenas de San Pedro, que comen lo mismo con adición de pulpo, avellanas y castañas ${ }^{119}$. Hay también testimonios más tardíos de visitas de los fieles a la tierra, referidos a las comidas y pagos que reciben estos oficiales para que den por buenos los pesos y medidas en las aldeas ${ }^{120}$.

En suma, teniendo en cuenta que muchos oficiales son pecheros y que las autoridades urbanas frecuentemente reclutan aldeanos para realizar pesquisas y amojonamientos o para actuar frente a ocupaciones de comunales en los lugares de la tierra, puede afirmarse que la gestión del espacio concejil se apoya en gran medida en el estamento pechero, lo cual podría expresar, antes que una conquista del sector, un rasgo funcional al perfil político de la oligarquía urbana, que tiende a desvincularse de la supervisión del ámbito rural y a concentrar su actuación en la representación de la jurisdicción frente a otros poderes o en la defensa del interés del concejo urbano ${ }^{121}$.

\section{AUTOGOBIERNO Y ELITE DIRIGENTE EN EL CONCEJO RURAL DE NAVARREDONDA}

Nos concentramos ahora en Navarredonda, el concejo rural más alejado de Piedrahíta, y en la actuación de los oficiales aldeanos. Este concejo comprende las aldeas de Navarredonda y Barajas. Si asumimos que las investigaciones que se efectúan en la comarca de La Sierra afectan estos lugares, según los datos de las cuentas de Piedrahíta debemos inferir un total de cinco pesquisas en más de 40 años, de las cuales sólo una se refleja claramente en la documentación local (la pesquisa de 1458).

\footnotetext{
117 Ibidem, p. 75.

118 Ibidem, p. 72.

119 Ibidem, p. 160.
}

120 "E se averiguó en mi consejo que los fieles de la dicha mi villa salen, en cada un año, a visitar la tierra (...) y que, aviendo de visitar los pesos y medidas de los conçejos y delos vezinos particulares, no lo cunplen asý, antes, se conçiertan con los conçejos e an conçertado e les llevan un çertum quid. Por todo ello, los pesos y medidas que visitan, aunque los hallan faltos e non buenos, los dexan quales se están, e asimismo, les an llevado en cada conçejo una comida", Luis López, Colección Documental del Archivo Municipal de Piedrahita, doc. 134 (1535).

121 Sánchez Benito concluye respecto al caso de Huete que el sistema concejil era fluido y flexible y que podía redundar en beneficios para otros sectores, por ejemplo mediante el ortorgamiento de licencias por fuera de la legalidad; destaca también la preferencia de los regidores por intervenir en asuntos concernientes a la jurisdicción, aunque considera de importancia el papel de aquéllos en el control de la vida aldeana, SÁNCHEZ BENITO, "El poder en una ciudad castellana". 


\subsection{EL CONCEJO RURAL Y LA AUTONOMÍA ALDEANA}

En Navarredonda el estrato enriquecido domina el concejo rural. Esto se deduce de una ordenanza que el concejo modifica según la cual para ejercer los cargos de alcalde y alguacil era condición ser pechero entero -la nueva disposición limita esta exigencia al oficio de alguacil ${ }^{122}$. Los aldeanos renuevan anualmente dos alcaldes y dos jurados, y cuentan con un procurador que actúa en representación del concejo rural ${ }^{123}$. Los actos del concejo se formalizan con la presencia de alguno de estos oficiales, a veces dos o tres testigos y el escribano de los hechos del concejo, que suele ser sacristán o a veces un clérigo que ostenta su rango firmando en latín. La voz concejo, además de designar a la institución concejil aldeana se identifica con el conjunto de vecinos $^{124}$, con los que concurren a las reuniones abiertas ${ }^{125}$, y con el grupo de oficiales $^{126}$. En ocasiones éstos toman decisiones "por el poder que el dicho conçejo les dio" 127 , guiados por "lo mejor que Dios les diese a entender" 128 .

El control del concejo rural por parte del segmento acomodado se refleja en la normativa que aquél produce. Una ordenanza de 1472 permite llevar a la dehesa concejil hasta dos pares de bueyes, aunque los que lleven menos podrán también llevar vacas ${ }^{129}$. La norma parece contemplar el uso más o menos equitativo de la dehesa. Una ordenanza posterior, sin embargo, establece que se podrán llevar hasta tres pares de bueyes y un holgón ${ }^{130}$, lo que atestigua no sólo que hay vecinos con medios de producción sustanciales sino también la influencia creciente de estos vecinos en la elaboración de las normas locales.

La existencia de ordenanzas locales es expresión del autogobierno aldeano ${ }^{131}$. Del conjunto de ordenanzas que registra el cuaderno de Navarredonda, además, una sola

122 "Otrosí ordenaron día de San Lucas, año de setenta e tres años, sobre rrazón que fasta agora era costunbre que qualquiera que non fuese pechero entero que non fuese alcalde nin qualquiera que fuese pechero entero non fuese aguazil, de aquí adelante ordenamos e tenemos por bien que qualquiera que fallaren que es pertenesçiente para alcalde que sea alcalde, aunque non sea pechero, e el que fuere pechero que sea alguazil sy non fuere pertenesçiente para alcalde", Del Ser Quijano, Documentación Medieval en Archivos Municipales Abulenses. Documentación Medieval del Archivo Municipal de Navarredonda de Gredos, doc. 1, 60 (p. 208).

123 "Pareçieron presentes en el dicho conçejo Juan Martín Lázaro, procurador del dicho conçejo de Navarredonda, e, de la otra parte, Pero Sánchez (...), como procurador que se mostró por el conçejo de San Martín del Pinpollar", Ibidem, doc. 1, 65 (p. 210).

124 "E, sacado el fruto, que lo dexe abierto para conçejo", Ibidem, doc. 1, 125 (p. 223).

125 "Este dicho día, estando el conçejo ayuntado a canpana rrepicada según lo an de uso y costunbre (...) acordaron todos que eligesen seys o siete buenos onbres con los alcaldes e jurados para que fuesen a ver e amojonar la dicha defesa", Ibidem, doc. 1, 125 (p. 222).

126 "Y entonçe el conçejo, mirando sus ordenanças, fallaron que tenía pena de sesenta maravedís (...) e mandaron taner la canpana e fuéronlos abener", Ibidem, doc. 1, 158 (p. 228).

127 Ibidem, doc. 1, 206 (p. 238).

${ }^{128}$ Ibidem, doc. 1, 125, p. 222.

${ }^{129}$ Ibidem, doc. 1, 57 (p. 208).

${ }^{130}$ Ibidem, doc. 1, 215 (p. 239).

131 También existen ordenanzas locales del concejo rural de Aldehuela de 1497 según DE SANToS Canalejo, "Piedrahíta", pp. 1148-1149. García Garcimartín, Articulación jurisdiccional, pp. 445-448 hace referencia a ordenanzas locales en algunos lugares de la zona del valle del Alberche, aunque considera que se trata de un fenómeno marginal; en su opinión los concejos rurales se caracterizan por la falta de iniciativa y 
tiene la aprobación de una autoridad urbana ${ }^{132}$, que como ya observamos se encontraba en el lugar por otros motivos.

Navarredonda cuenta con pinares propios, lo que atestigua también la autonomía de este concejo rural -cuyo carácter relativo, por otro lado, se evidencia en la imposición de abastecer de madera a la villa ${ }^{133}$. El concejo rural regula el usufructo local de los pinares aldeanos ${ }^{134}$ y el trabajo asalariado de los aserradores ${ }^{135}$, lo cual señala la magnitud y desarrollo de una actividad productiva controlada por las autoridades locales.

De acuerdo a la inclinación a distribuir funciones coercitivas el señor delega en las comunidades rurales el control del conflicto interno. La normativa de Piedrahíta prohíbe a los de la tierra llevar sus casos a los tribunales urbanos, que se ocuparán únicamente de las causas criminales y de las que excedan cierto monto, aunque los aldeanos podrán apelar en esta instancia las sentencias dictadas por los alcaldes locales ${ }^{136}$. El concejo rural de Navarredonda tiene al respecto sus propias normas: aquel que apelara una sentencia en Piedrahíta sin avisar a las autoridades aldeanas pagará una multa, y si éstas consideraran justa la sentencia local, pagará otro tanto ${ }^{137}$. Otras dos ordenanzas de Navarredonda penalizan al que llevara sus querellas al tribunal de Piedrahíta sin darlo a entender a los alcaldes de la aldea ${ }^{138}$, lo que confirma la importancia que conceden las autoridades locales a la regulación autónoma del conflicto interno. Estas ordenanzas no son las mismas que el concejo de Navarredonda envía al conde de Alba cuando en 1459 éste requiere de los lugares de la tierra "las ordenanças todas que tenían fechas en sus conçejos" ${ }^{139}$. Entre las ordenanzas que

la subordinación a las ordenanzas del concejo urbano. Esta situación indicaría un contraste con nuestro caso de estudio

132 Del Ser Quijano, Documentación Medieval en Archivos Municipales Abulenses. Documentación Medieval del Archivo Municipal de Navarredonda de Gredos, doc. 1, 53 (p. 207).

133 Poseen pinares aldeanos los concejos rurales de Navarredonda, San Martín del Pimpollar y Hoyos y Hoyos, Luis López, Colección Documental del Archivo Municipal de Piedrahíta, doc. 2 (1405) y 121 (1527); el compromiso de estos concejos de vender madera a la villa en Luis López, Documentación medieval de Piedrahita, vol. III, doc. 38, 39, 40 y 41. Analiza este último problema Colombo, "Producción campesina y poder concejil".

134 Del Ser Quijano, Documentación Medieval en Archivos Municipales Abulenses. Documentación Medieval del Archivo Municipal de Navarredonda de Gredos, doc. 1, 3, 7 (pp. 199-200), 62 (p. 209), 71 (p. 211), 85 (p. 214), 208 (p. 238).

${ }^{135}$ Ibidem, doc. 1, 199 (p. 236).

${ }^{136}$ Luis López, Colección Documental del Archivo Municipal de Piedrahíta, doc. 65.

137 "Otrosí ordenó el concejo que qualquiera que apelare de la sentençia que el alcalde del conçejo diere, e siguiere el apelaçión syn fazerlo entender a aquellos que tienen el cargo del conçejo, que aya e caya en pena de sesenta maravedís; e, si aquellos omes buenos fallaren que la sentençia es bien dada, que pague todavía el apelaçión el alcalde aquel que apeló", Del Ser Quijano, Documentación Medieval en Archivos Municipales Abulenses. Documentación Medieval del Archivo Municipal de Navarredonda de Gredos, doc. 1, 14 (p. 201).

138 "E toviereon por byen que quando oviere debate entre algunas personas deste lugar, que, primero que se emplazen para Pyedrafita, lo den antender a los alcaldes e a los que tovieren cargo del conçejo, so pena de sesenta maravedís", Ibidem, doc. 1, 5 (p. 200); "Otrosí ordenaron, si por aventura acaesçiere que alguno aya de yr a Perafita a dar querella de otro, que non sea osado de yr a dar la tal querella sin darlo ha entender los alcaldes e los omes que tienen el cargo del conçejo con ellos, so pena de sesenta maravedís", Ibidem, doc. 1, 15 (p. 201).

139 Del Ser Quijano, Documentación medieval de Piedrahita, vol. II doc. 143 (1459). 
envía el concejo de Navarredonda no figura aquella que prohíbe apelar una sentencia en Piedrahíta, dictada un año antes, de lo cual se deduce que las autoridades rurales elaboraban sus leyes sin ignorar que éstas contradecían la normativa emanada del poder superior. El breve corpus de normas enviadas al señor contiene regulaciones ajenas a las ordenanzas locales, lo cual podría sugerir que ese corpus ha sido elaborado para la ocasión: las disposiciones establecen penas para los que jugaran a los dados, fueran a pescar de noche, apuntaran con armas o dijeran "palabras vedadas", una normativa naïf muy alejada del contenido principalmente agrario del cuaderno. El corpus de normas que el concejo rural envía al conde contiene también una versión edulcorada de las ordenanzas que prohíben llevar acusaciones a Piedrahíta, en la cual se contempla la posibilidad de acudir a un tribunal superior si fracasara el intento de arreglo interno ${ }^{140}$. La retórica condescendiente del texto, que no obstante mantiene la pena de sesenta maravedíes para el que desconociera a los oficiales del lugar, podría indicar que éstos buscaban legitimar una norma que expresa un principio de autonomía del concejo rural, autonomía que en la práctica se manifiesta en el dictado de ordenanzas independientes de las normas generales. El envío de ordenanzas al señor tiene también el objetivo de validar internamente la actuación de los dirigentes aldeanos; esto se sigue de otra disposición según la cual el conjunto de vecinos aceptará lo que decidan los alcaldes y hombres buenos elegidos en el lugar ${ }^{141}$, lo que matiza la importancia del concejo abierto. Estas normas son aprobadas por el conde, que emite un texto igualmente formalista que prohíbe al concejo rural dictar nuevas ordenanzas sin consultar a las autoridades urbanas o señoriales ${ }^{142}$.

El autogobierno aldeano no es un aspecto menor. Al contrario, aparece como una de las principales aspiraciones de las comunidades rurales en la Baja Edad Media, como lo ejemplifica una de las demandas del levantamiento inglés de 1381, referida al control aldeano de las funciones de justicia y policía ${ }^{143}$. Al respecto se ha sugerido que los rebeldes habrían concebido la posibilidad de una confederación de aldeas au-

140 "Más ordenaron que, quando oviere debate entre algunas personas del dicho lugar, que, primero que se emplacen para Piedrahíta, lo den a entender a los alcaldes que tovieren cargo del conçejo, porque los ygualen, sy pudieren; e, sy non, que estén tres días e a cabo de tres días que vayan a Piedrahíta. E, sy non lo dieren a entender a los alcaldes del dicho lugar primero, que cayan en pena de sesenta maravedís. Otrosý, ordenaron que qualquiera que fuere a dar querella a Piedrahíta de persona del dicho conçejo, salvo sy fuere crimen, que caya en pena de treinta maravedís; los veinte para conçejo e los diez para el alcalde en nombre de señal. Esto se entyenda sy primero non lo denunçiare a los alcaldes del dicho lugar; mas, denunçiándogelo, sy dentro de tres días non lo ygualaren o despacharen, que después pueda yr a los alcaldes de Piedrahíta”, Ibidem, doc. 142 (1458).

141 "Más ordenaron que de cada un año que tengan cargo de los fechos del conçejo seys onbres buenos con los alcaldes e que sean juramentados. E el conçejo, estando a canpana rrepicada, les dio e da poder conplido para que todas las cosas que ellos fizieren que las dé el conçejo por firmes e valederas", Ibidem.

142 "Yo, el conde, vi las ordenanças susodichas, que el conçejo de Navarredonda e omes buenos me enbiaron, las cuales son buenas e las confirmo e mando que usen dellas. E, sy otras algunas paresçieren, mando que non valan nin usen dellas nin asymismo puedan fazer otras de nuevo syn primeramente consultar conmigo o con los rregidores de la dicha mi villa", Ibidem, doc. 143 (1459).

143 Según Dyer, "The English Medieval Village Community”, p. 417, este sería el sentido de una de las demandas de Smithfield ("and he asked that there should be no law except for the law of Winchester", en Anonimalle Chronicle, cit. por Dobson, The Peasants'Revolt of 1381). 
togobernadas como alternativa al orden feudal ${ }^{144}$, y se atestigua también la conformación de tribunales campesinos durante la revuelta ${ }^{145}$, lo que confirma la importancia del reclamo de autogobierno. Tomando en cuenta esta perspectiva, la defensa de la autonomía aldeana que observamos en Navarredonda podría comprenderse como expresión de un anhelo general del campesinado (o de sus líderes), con independencia del formato señorial específico en el que se encuadre.

Las autoridades rurales procuran resolver internamente el conflicto interaldeano. El cuaderno de acuerdos registra el compromiso del concejo de Navarredonda y el de San Martín del Pimpollar con dos vecinos de Navadijos, aldea del concejo rural de La Garganta del Villar, por un problema de términos que afectaba sus posesiones particulares; estos vecinos habían llevado antes su caso al corregidor de Piedrahíta y quieren ahora llegar a un acuerdo. Por haber salido el caso del ámbito aldeano, el acuerdo se suscribe a condición de que los afectados ignoren la sentencia del corregidor, si éste impusiera penas a los concejos ${ }^{146}$. Este caso motiva una nueva ordenanza del concejo de Navarredonda, que considera delatores a los que acudieran a las autoridades urbanas para resolver disputas internas: el que "mesturare a otro" pagará una multa, a menos que el daño afecte los pinares aldeanos, en cuyo caso será sancionado el que "encobriere" al infractor ${ }^{147}$. Significativamente, el resguardo de la autonomía aldeana, sustancia de esta ordenanza, se expresa como prohibición o deber, según se trate del interés individual o comunal, de dar a conocer un secreto, lo que descubre el valor primordial que tiene el autogobierno para los dirigentes aldeanos. Por otro lado, la diferencia entre el vocabulario de uso interno y el de las ordenanzas que se envían al conde revela la adaptación del discurso a la audiencia de la cual depende la afirmación de la autonomía aldeana, autonomía que implica no sólo la actuación independiente con respecto al señor o al centro urbano (consumada de facto o eventualmente avalada por el poder superior) sino también el disciplinamiento del conjunto de moradores.

Algunos de estos moradores tienen posesiones en lugares vecinos, según lo atestigua un acuerdo sobre pastos entre Navarredonda y la aldea vecina de Hoyos del

144 DYER, "A Redistribution of Incomes". Sobre el papel de los marcos organizativos aldeanos en la revuelta de 1381 Hilton, Siervos liberados, pp. 286-290.

145 Whittle, "Peasant Politics and Class Consciusness", p. 236.

146 "E, por quanto este pleyto avía sydo puesto ante el corregidor, los dichos conçejos, Navarredonda e San Martín, se rreçelavan de lo fazer por estar ya puesto ante el corregidor, se obligaron los dichos Françisco Jiménez e Juan Sánchez de sacar a paz e a salvo a los dichos conçejos de la pena del dicho corregidor, si la devían dar", Del Ser Quijano, Documentación Medieval en Archivos Municipales Abulenses. Documentación Medieval del Archivo Municipal de Navarredonda de Gredos, doc. 1, 65 (p. 210).

147 “Otrosy ordena más todo el conçejo ayuntado a canpana rrepicada según an de costunbre, sobre rrazón de qualquiera que mesturare a otro en qualquier cosa que le venga mal o daño en esta tierra o en otras tierras qualesquier que sean, que aya en pena sesenta maravedíes e más quanto el conçejo quisiere, salvando de sy fuere furto o del pinar del conçejo. E estas dos cosas, así el furto conmo el pinar del conçejo, cualquiera que las encobriere que ayan la pena susodicha. E, si alguno mesturare a otro vezino deste pueblo conmo dicho es, porque le venga daño a él o a su fazienda, que pague todo el daño que por la dicha rrazón le veniere e más la pena al conçejo susodicho", Ibidem, doc. 1, 66 (p. 210). Esta ordenanza, según la información que proporciona el editor del documento, está escrita en una solapa en el folio correspondiente al caso de los de Navadijos. La reunión debió ser concurrida y el debate muy intenso, según se sigue de otra ordenanza dictada ese mismo día que penaliza al que insultara al alcalde cuando estuviera librando pleitos, Ibidem, doc. 1, 67 (p. 210 ). 
Espino $^{148}$; lo mismo se confirma en un acuerdo de vecindad entre Piedrahíta y El Bar$\mathrm{co}^{149}$. La dispersión de bienes en distintos concejos implica no sólo niveles de riqueza que podrían ser significativos sino también posibilidades de evasión tributaria, que en este caso redunda en una redistribución de la renta. Una ordenanza del concejo urbano se refiere a los que se empadronan en el lugar donde tienen menos posesiones, aprovechando la ausencia de restricciones a la movilidad dentro de un mismo señorío (en este caso, el señorío de Valdecorneja) ${ }^{150}$. La difusión de esta práctica motiva la convocatoria a una junta para tratar el problema, a la que deben concurrir procuradores y autoridades de los concejos de Valdecorneja. En el caso de esta junta en particular, que involucra a los concejos de Piedrahíta y El Barco, los regidores se ausentan, lo que podría señalar su desinterés por un problema que concierne a los que tributan, o bien afinidades subterráneas con los pecheros evasores ${ }^{151}$. La falta de pesquisas a las aldeas por parte de las autoridades urbanas podría también comprenderse desde esta perspectiva.

\subsection{PRÁCTICAS AGRARIAS DE LOS OFICIALES ALDEANOS: LA DIFUSIÓN DE CERRADOS}

Al igual que en otros concejos en Navarredonda las tierras de diverso tipo están sujetas a sistemas de aprovechamiento específicos. Los linares, en los que se cultiva trigo, centeno y lino, se abren al uso común en julio, el día de Santiago; los prados, en junio, el día de San Juan, y en las tierras de cereal, abiertas desde marzo, rige un sistema de cultivo a tercio, por el cual la tierra se cultiva un año y descansa dos, convirtiéndose en pasto común ${ }^{152}$. Existen además heredades cercadas, en las que el titular goza los

148 “Otrosí ordenaron (...) que puedan paçer sin pena ningun mientra labrare o sacare el fruto de su heredat, ansí los de Navarredonda que fueren allá commo los de Los Foyos que venieren acá”, Ibidem, doc. 1, 219 (p. 241).

149 "E los que tienen heredades en tierra de Piedrafita biven en tierra del Varco, e otros tienen heredades e prados en tierra del Varco e biven en tierra de Piedrafita (...) dizen que los dexen regar las heredades que tienen los vezinos de Piedrafita en término del Varco", Luis López, Colección Documental del Archivo Municipal de Piedrahíta, doc. 28 (1477). Sobre el fenómeno de la doble vecindad puede verse CLEMENTE RAmos, "La explotación económica del Campo Arañuelo". El autor analiza las diversas motivaciones y formas de doble residencia así como la conflictividad que genera el intento de regular esta práctica en un sector de Plasencia sometido a distintas jurisdicciones pero concebido como unidad desde el punto de vista de la explotación agropecuaria.

150 "E qualquier pechero que fuere a morar de un lugar a otro, quel conçejo a do fuere a morar el tal pechero que lo cargue en su cabeça que toviere, e sea descargado el conçejo do salió (...) Esto por razón de las ynfurtas que se fazen, cohechándose los pecheros por los conçejos. E esto se debe entender quando el tal vezino se fuere del lugar del mesmo señorío, pero, sy fuere a otro lugar de otro señorío, que peche por los bienes que dexare, en el lugar de donde se fue, segund las leys de estos reynos", Ibidem, doc. 65 (1499).

151 "Gasto que se fizo en Aldeanueva, sobre las yuntas que se fizieron con los del barco, sobre los pecheros que se pasan de un término a otro e sobre el paçer de los ganados (...). Dy a un onbre que llevó una carta de los regidores a la villa del Barco, sobre las yuntas que estaban contentados en Aldeanueva, porque no podieron yr allá los regidores, diez maravedíes", TENA GARCíA, Las finanzas de un concejo castellano, vol. V, p. 39 y p. 59.

152 Sobre el régimen de aprovechamiento en panes, linares y prados LuIs López, Colección Documental del Archivo Municipal de Piedrahíta, doc. 77 y 118, y Del Ser Qujuano, Documentación Medieval en Archivos Municipales Abulenses. Documentación Medieval del Archivo Municipal de Navarredonda de Gredos, doc. 1, 125 (pp. 222-223), 219 (pp. 240-241). 
derechos de pasto de manera exclusiva, sustrayendo su parcela del uso colectivo de manera permanente. Estos "cerrados", a los que hacían referencia los balances de cuentas, se atribuyen a los descendientes de los vecinos más antiguos ${ }^{153}$.

El cuaderno de Navarredonda registra un conjunto de compras, trueques y arreglos efectuados por el concejo rural. El análisis del conjunto de transacciones y el seguimiento de la actuación patrimonial de algunos sujetos revela que los sectores destacados de la aldea (generalmente oficiales y sus allegados y parientes) realizan arreglos que implican alteraciones en los usos colectivos y una merma del pasto común; con la mediación del concejo rural estos sectores cambian de cultivo, reagrupan bienes dispersos mediante trueques y tras amalgamar posesiones las cierran al aprovechamiento común en forma permanente, privando a los demás vecinos de las prácticas que contempla el sistema de campo abierto en las heredades particulares. Las heredades cerradas, antiguas o de reciente conformación, tienden a ampliarse mediante la incorporación de terrenos concejiles de los alrededores, lo cual se consigue cediendo al concejo rural bienes en otro lugar ${ }^{154}$. Este proceso (el reagrupamiento y posterior vallado de la heredad por parte de campesinos prósperos) ha sido descrito por Tawney para la Inglaterra de 1381-1489, periodo que supone un debilitamiento de los vínculos coercitivos ${ }^{155}$. En nuestro caso, el proceso tiene como condición básica la capacidad de disposición patrimonial y la laxitud de los controles que caracteriza la gestión del señorío concejil.

Los cerrados (principalmente prados) se dedican a la producción ganadera, aunque se observa también la expansión del cultivo de lino, probablemente asociado al desarrollo de la nueva pañería en Piedrahíta. Esta especialización se consigue cediendo al concejo tierras a cambio de linares ${ }^{156}$, o negociando el permiso para cambiar la dedicación productiva y singularizar la explotación ${ }^{157}$. El procurador Alonso Fernández de la Calleja, por ejemplo, intercambia con el concejo ciertas porciones de tierra por una parcela lindera a su linar, obteniendo además dinero ${ }^{158}$; este linar ampliado aparece después como cerrado y como punto de referencia, lo que sugiere dimensiones significativas ${ }^{159}$.

153 Luis López, La Comunidad de villa y tierra de Piedrahita, p. 376.

154 Esto ha sido en parte analizado en DA GRACA, "Intercambio de tierras". Retomamos aquí algunos casos sobre los cuales contamos con nueva información.

155 TAWNEY, The agrarian problem, pp. 72-97.

156 Del Ser Quijano, Documentación Medieval en Archivos Municipales Abulenses. Documentación Medieval del Archivo Municipal de Navarredonda de Gredos, doc. 1, 24 (p. 203), 132 (p. 225), 141, 142 145, 146, 149 (p. 226), 163 (p. 230), 202 (p. 236).

157 Por ejemplo "Este dicho día dio Juan Moreno al conçejo un prado que él tenía en [e]l Fortilejo, e diole el conçejo a él en Navafondilla (...), donde faga un linar o prado o lo que quisiere fazer, e lo pueda çerrar e fazer dello lo que quisiere", Ibidem, doc. 1, 117 (p. 220).

158 "Este dicho día dio Alonso Ferrández de la Calleja al conçejo un pedaço de tierra e otro de prado (...) e dióle el conçejo a él por esto un girón arrimado al su linar (...) e por la demasýa pagójelo el concejo", Ibidem, doc. 1, 110 (pp. 218-219).

159 "Dio Diego Sánchez Carrasco al conçejo un pedaço de tierra (...) e dióle el conçejo a él por esto para un linar fondón del era de Alonso Sánchez de la Iglesia, arrimado al linar de Alonso Ferrández de la Calleja", Ibidem, doc. 1, 145 (p. 226); el mismo año "dio Alonso García el Coxo al conçejo un pedaço de tierra (...) e dióle el conçejo a él para un linar al prado La Laguna, arrimado a la çerrada del de la Calleja”, Ibidem, doc. 1,146 (p. 226). 
Nuestro procurador ha sido testigo de la ampliación de un cerrado, como veremos luego, y en 1466 contribuye con el concejo para que el alcalde de ese año reagrupe bienes, proporcionando al concejo la tierra que el alcalde necesitaba ${ }^{160}$. Veamos la actuación de este alcalde, Alonso García de la Calle. Durante su mandato debe ocuparse de las maniobras que está realizando uno de los vecinos más poderosos del lugar, Alonso Martínez de Barajas, que figura como propietario de varios cerrados y que está ampliando uno de ellos a costa de tierras concejiles ${ }^{161}$. Se trata de un personaje destacado que en 1465 actúa como sexmero por Navarredonda ${ }^{162}$, ha vendido toros de lidia al concejo urbano ${ }^{163}$ y frecuenta el concejo vecino de Arenas de San Pedro, donde es conocido y al parecer, temido ${ }^{164}$. Es también uno de los afectados por la pesquisa de 1458, lo cual no le ha impedido continuar su política de apropiación del espacio en los años siguientes. En 1466 este sexmero ofrece al concejo aldeano tierras en otra zona a cambio de mantener "lo que tenía tomado de lo de conçejo e metido en su çerrada". Allí se dirige el alcalde, junto con otros oficiales; Alonso Martínez "dióles tierra con que ellos fueron agradados". Las tierras ofrecidas se describen sin embargo como bastante modestas, y el arreglo incluye un pago de cuarenta maravedíes al usurpador ${ }^{165}$. El caso ilustra la subordinación del concejo rural a los intereses de los sectores acomodados, a la sazón representantes pecheros.

En cuanto al alcalde García de la Calle, ha realizado un trueque similar diez años atrás para mantener los terrenos concejiles incorporados a su cerrado, lo que de-

160 "Este dicho día tomaron a Alonso García de la Calle otro pedaço para la dicha cañada (...) E diéronle por ello otro pedaço de tierra de Alonso Ferrández de la Calleja (...) que están de la otra parte, tierra del dicho Alonso Garçia de la Calle; e al dicho Alonso Ferrández diéronle un prado que está en Navafondilla", Ibidem, doc. 1,83 (p. 214).

${ }^{161}$ Alonso Martínez de Barajas realiza varios trueques con el concejo de la aldea: en 1450 da un prado "por lo quél tenía de conçejo çerrado en la çerrada de la Gargantilla"; en 1458 debe "echar la pared por lo suyo" y dejar lo que pertenece al concejo en Los Arroyos, Ibidem, doc. 1, 11 (p. 201), 42 (p. 205).

162 Luis López, Documentación medieval de Piedrahita, vol. III, doc. 117 (1465).

163 Monsalvo Antón, Las finanzas de un concejo castellano, vol. IV, p. 101, 104 y 173.

${ }^{164}$ En una carta al concejo de Piedrahíta los de la villa de Arenas expresan: "Ya sabedes la fabla que se ovo en Navarredonda sobre rrazón de la saca de la madera e otros dares e tomares entre ambas villas e sus tierras, lo cual entonçes non se concluyó. E agora, vinieron por aquí de sus ganados Alonso Garçía, de Navaçepeda, e Alfonso Martínez, de Varajas, e ovimos fabla con ellos e ellos con nosotros. E en conclusión, sabed que nuestra intençión es de nos aver bien con todos los comarcanos, mayormente con vosotros. Por ende, los que quisieren venir desa villa e su tierra a esta villa, por madera o vino o por otros metales que por ella ayan, vengan llanamente e dárseles ha por sus dineros conmo antiguamente se dio, guardemos las buenas vezyndades que siempre se guardaron. E vos rrogamos que, sy algunas prendas son tomadas a qualquier persona que acá veniese por vino o traxo otra qualquier mercaduría desta tierra, que ge las mandedes dar por amor nuestro", Luis López, Documentación medieval de Piedrahita, vol. III, doc. 23 (1462).

165 "Este dicho día se abinieron los alcaldes e los buenos onbres juramentados con Alonso Martínez de Varajas sobre un pedaço de tierra quél tenía tomado en el Rrebanal de lo de conçejo e metido en su çerrada; lo qual visto por los alcaldes Alonso Garçía e Martín Ferrández e los que con ellos son, fueron al Fortigal con el dicho Alonso Martínez e dióles tierra con que ellos fueron agradados (...), la qual tierra es un pedaçuelo que está a la entrada del Fortigal debaxito de una fontanilla, e más otro girón arriba a la rrenconada de este mesmo prado e más otro girón que estava a par dello. Rrogáronle estos buenos onbres que lo dexase a conçejo, porque oviese entrada al dicho prado por allí, e le pagarían lo que meresçiese; por lo qual el dicho Alonso Martínez por el rruego destos buenos onbres plógole de lo fazer e abiniéronse con él por quarenta maravedís", DeL SER Quisano, Documentación Medieval en Archivos Municipales Abulenses. Documentación Medieval del Archivo Municipal de Navarredonda de Gredos, doc. 1, 77 (p. 212). 
muestra la continuidad de esta práctica ${ }^{166}$. Otros miembros de la familia han actuado también contra los intereses comunitarios: su padre tiene un cerrado en otro lugar ${ }^{167}$, y su primo, Juan Redondo, tal vez con menos influencia, ha esperado diez años para reagrupar la tenencia. Este caso ilustra el intento de convertir tierras de cultivo en prados. La preferencia de este sujeto por la ganadería queda sugerida en los libros de cuentas de Piedrahíta, donde se lo menciona como vendedor de toros (junto a Alonso Martínez de Barajas) en 1457 y en $1460^{168}$, actividad que retomará su yerno en $1462^{169}$. Según los datos del cuaderno de Navarredonda, en 1464 Juan Redondo ha enajenado tierras ${ }^{170}$. En 1467 debe afrontar un pleito a raíz de una tierra que posee en otra zona, El Fortigal, por explotarla como prado y no observar el régimen de aprovechamiento colectivo. Este pleito es promovido por el procurador Fernández de la Calleja ante el flamante alcalde de la Mesta, residente en Navarredonda ${ }^{171}$, lo que podría explicar la falta de apoyos al apropiador Juan Redondo, que pierde el caso tras las declaraciones desfavorables de dos titulares de cerrados, entre ellos su tío ${ }^{172}$. No obstante, pasado el pleito Juan Redondo persevera. En 1470 el concejo compra una tierra en la zona del conflicto, lindera a sus posesiones ${ }^{173}$; dos años después Juan Redondo obtiene por trueque con el concejo la parcela objeto de la anterior operación, lindera a la suya ${ }^{174}$. Con la mediación del concejo rural Juan Redondo ha logrado

166 "Este dicho día dio Alonso Garçía de la Calle, fijo de Juan Sánchez, el Viejo, un pedaço de prado (...) Esto dio el dicho Alonso Garçía por lo que tiene çerrado en la çerrada de Navafondilla de lo del conçejo", Ibidem, doc. 1, 18 (1457) (p. 202).

167 "Este dicho día dio Juan Sánchez, el Viejo, vezino desde dicho lugar, un pedaço de tierra (...) E le da al conçejo por lo que él tenía çerrado en la çerrada de la Defesilla que era de conçejo", Ibidem, doc. 1, 22 (p. 203).

168 Monsalvo Antón, Las finanzas de un concejo castellano, vol. IV, p. 101, 104 y 173.

169 Tena García, Las finanzas de un concejo castellano, vol. V, p. 38.

170 "Este dicho día dio Diego Sánchez de Varajas una tierra que está a la cabeçada de la Cepeda El Alcalde, la qual tierra era de Juan Redondo", Del Ser Qujano, Documentación Medieval en Archivos Municipales Abulenses. Documentación Medieval del Archivo Municipal de Navarredonda de Gredos, doc. 1, 74 (p. 211 ).

171 “Ante Alonso Sánchez de los Pinos, alcalde en el dicho lugar e del onrrado conçejo de la Mesta, paresçió ante el dicho alcalde Alonso Fernández de la Calleja, procurador de dicho conçejo e puso por demanda a Juan Sánchez Rredondo en que el dicho Juan Sánchez guardase el prado que dicen del Fortigal Mayor, non lo podiendo fazer de derecho, dos años que el conçejo avía de posesión en el dicho prado, e que el dicho Juan Rredondo non á por qué guardar el dicho prado salvo el año que es panes", Ibidem, doc. 1, 26 (p. 203-204). Sobre el alcalde de la Mesta vid. nota 71. En 1467 este oficial acompaña a las autoridades a El Colmenar por un problema sobre el servicio de montazgo (Luis López, Colección Documental del Archivo Municipal de Piedrahíta, p. 343), por lo que éste podría ser el año de su nombramiento.

172 "El sobredicho Alonso Fernández presentó por pruevas a Juan Sánchez, el Viejo, su tío, hermano de su padre del dicho Juan Redondo, e a Alonso García de los Pinos", Del Ser Quijano, Documentación Medieval en Archivos Municipales Abulenses. Documentación Medieval del Archivo Municipal de Navarredonda de Gredos, doc. 1, 26 (p. 203). Sobre la actuación de estos sujetos Ibidem, doc. 1, 12 (1457) y 22 (1458) (pp. 201-203).

173 "En el año de setenta conpró el conçejo un pedaço de tierra en el Fortigal con un pedaço de prado que era de Juan Mateos de los Hoyos (...) e quanto a lo de Fortigal son linderos, de la una parte, tierra de Juan Rredondo", Ibidem, doc. 1, 96 (p. 216).

174 “Año de setenta e dos años. Este dicho día dio Juan Redondo un pedaço de tierra que tiene en Cepeda el Alcalde al conçejo por otro pedaço de tierra que le dio el conçejo a él en el Fortigal que avíe conprado el conçejo de Juan Mateos de los Foyos (...) que alinda con tierra del dicho Juan Rredondo", Ibidem, doc. 1, 108 (p. 218). 
reagrupar sus bienes, condición necesaria para privatizar la tenencia, una práctica sobre la cual ya ha mostrado antecedentes. Estos no le impiden desempeñarse como alcalde unos años después ${ }^{175}$.

Las tierras enajenadas sirven a otras transacciones dentro del círculo acomodado: el que obtiene una de las tierras de Juan Redondo, Diego Sánchez de Barajas, la entrega al concejo a cambio de mantener los terrenos concejiles incorporados a su cerrado ${ }^{176}$. Este sujeto participa activamente de la vida política local: aparece como testigo en dos acuerdos con aldeas vecinas, y diez años después de la operación en la que consolida un cerrado se desempeña como alcalde ${ }^{177}$. Antes ha sido jurado, al igual que sus tres hermanos, que también han ejercido distintos oficios; uno de ellos fue alcalde y se ha apropiado las tierras de los alrededores ${ }^{178}$, y otro además de jurado es carnicero y aparece reagrupando posesiones con ayuda del concejo ${ }^{179}$. El mismo perfil se observa en la familia de los Fernández Buenadicha, que detenta cerrados y proporciona a Navarredonda alcaldes, jurados, escribanos, testigos, sacristanes, procuradores y sexmeros. Esta última función no es incompatible con la apropiación del espacio comunal; hemos observado ya la actuación de Alonso Martínez de Barajas; otro sexmero de Navarredonda, Fernán Sánchez de los Pinos, negocia la ampliación de un cerrado a costa de tierras concejiles ${ }^{180}$, y su vecino, un alcalde que actúa después como testamentario suyo ${ }^{181}$, transmite al hijo no sólo este oficio sino también la práctica de cercar ${ }^{182}$.

Estas operaciones se formalizan con la presencia de unos pocos testigos, que, por otro lado, han realizado también cercamientos: el análisis de los casos revela que las mismas personas intercambian roles, actuando como testigos unos de otros. Por ejemplo, en 1450 Alonso Martínez de Barajas hace un arreglo que tiene como testigo al procurador Alonso Fernández de la Calleja, y en 1457 actúa como testigo de Alonso García de los Pinos; este último es testigo del cercamiento que realiza Alonso García de la Calle, quien siendo alcalde en 1466 contribuye a la ampliación de un ce-

175 Ibidem, doc. 1, 130 (p. 224).

176 "Este dicho día dio Diego Sánchez de Varajas una tierra que está a la cabeçada de la Cepeda el Alcalde, la qual tierra era de Juan Redondo (...) e diolo por lo que cerró de conçejo en una cerrada al prado Juan Miguel", Ibidem, doc. 1, 74 (p. 211).

177 Ibidem, doc. 1, 62 (p. 209), 65 (pp. 209-210) y 116 (p. 220).

178 "Más dio Pero Sánchez de Varajas en el prado (...) por lo que tomó el dicho Pero Sánchez en la ysla cabe el su molyno", Ibidem, doc. 1, 49 (p. 206). En otra operación son testigos "Diego Sánchez de Varajas e Pero Sánchez, su ermano (...) e otros buenos onbres", Ibidem, doc. 1, 208 (p. 238).

179 "Dio Fernán Sánchez de Varajas al conçejo un pedaço de prado e de tierra (...) e dióle el conçejo a él un girón en los arroyos, cabe el su prado", Ibidem, doc. 1, 160 (p. 229).

180 "Este dicho día dyo Ferrán Sánchez de los Pynos un prado que él avía en la Defesylla e un pedaço de tierra para pasada que es en los Arroyos, fondón de la çerrada de Alonso Martín. E esto dyo el dicho Ferrán Sánchez al conçejo por lo que él tyene en la su çerrada de los Arroyos tomado de lo de concejo", Ibidem, doc. 1, 10 (1452) (p. 201). Fernán Sánchez de los Pinos figura como sexmero por Navarredonda en 1442, LuIS LóPEz, Documentación medieval de Piedrahíta, vol. I, doc. 79.

181 Del Ser Quijano, Documentación Medieval en Archivos Municipales Abulenses. Documentación Medieval del Archivo Municipal de Navarredonda de Gredos, doc. 1, 89 (p. 215).

182 Juan Martín de Navadijos, hijo de Alonso Martín de Navadijos, da al concejo tierras "por que cier[r]e la cerrada quel dicho Juan Martín tiene en los Nabarejos e lo manpare por cerradura e que goze del fruto e de la pastura", Ibidem, doc. 1, 72 (p. 211). 
rrado del ya sexmero Alonso Martínez de Barajas; en esta última operación participa como testigo Juan Martín de Navadijos, que ha obtenido un cerrado dos años antes con Alonso Martínez de Barajas como testigo. En las operaciones de 1457 figura como testigo Pedro Alonso, que vuelve a cumplir esta función para Diego Sánchez de Barajas en 1464; en 1470 un cerrado de Pedro Alonso aparece como lindero, y en 1472 Pedro Alonso es alcalde. En cuanto a Diego Sánchez de Barajas, será testigo junto a Alonso Martínez de Barajas de arreglos similares en 1474 y $1485^{183}$.

Debe valorarse el contraste respecto a la modalidad de las operaciones. En el caso de una venta efectuada mediante pregón se aclara: "non posimos testigos, que todo el conçejo estava ayuntado" 184 , lo cual sugiere que las operaciones detalladas -que a diferencia de esta venta implican una negociación con las autoridades concejiles- se llevan a cabo sin publicidad y dentro de un grupo pequeño de personas, y que las tierras objeto de intercambio no están disponibles para todos los vecinos. Se confirma, en suma, un funcionamiento cerrado de la comunidad política de la aldea paralelo al funcionamiento abierto del concejo rural.

En el cuaderno de Navarredonda se cuentan, en total, 22 cerrados. Entre sus titulares figuran tres sexmeros, tres alcaldes, un procurador, tres parientes de oficiales, un jurado y un carnicero; los demás han actuado reiteradamente como testigos, lo que confirma su residencia en el lugar ${ }^{185}$. Algunos de estos cerrados aparecen en los deslindes a lo largo de un extenso periodo de tiempo, lo que prueba que se consolidan, y constituyen además puntos de referencia, como en el caso del cerrado de Juan Martín de Navadijos, al que se alude para identificar un camino ${ }^{186}$. Este cerrado, conformado para que el titular "goze del fruto e de la pastura" en forma exclusiva ${ }^{187}$, ha pasado a sus herederos, al igual que el cerrado del sexmero mencionado antes.

Las heredades cerradas se atribuyen a privilegios antiguos. Esta temprana concesión por parte del señor pudo ser un mecanismo de reconocimiento y reafirmación de los líderes aldeanos, a partir de los cuales se constituye institucionalmente el concejo rural. El hecho de que los cerrados que se atestiguan en el siglo XV sean detentados por sujetos vinculados al gobierno local confirma la continuidad de esta elite, lo cual se expresa en la existencia de familias de oficiales. La consolidación del estrato enriquecido de la aldea se manifiesta en la ampliación de los cerrados ya existentes y

${ }^{183}$ Ibidem, doc. 1, 11 (1450), 12 (1457), 18 (1457), 72 (1464), 74 (1464), 77 (1466), 98 (1470), 117 (1474), 168 (1485) (pp. 201-202, 211-212, 216, 220, 230-231).

${ }^{184}$ Ibidem, 115 (p. 220).

${ }^{185}$ Ibidem, doc. 1, 8 (Juan Domínguez), 10 (Alonso Martín de Navadijos y Fernán Sánchez de los Pinos), 11 (Alonso Martínez de Barajas), 12 (Alonso García de los Pinos), 18 (Alonso García de la Calle), 22 (Juan Sánchez el Viejo), 42 (Alonso Martínez de Barajas), 72 (Juan Martín de Navadijos), 74 (Diego Sánchez de Barajas), 98 (Pedro Alonso), 114 (García Fernández), 117 (Alonso García de los Guindos y Juan Moreno), 125 (Juan García), 146 (Alonso Fernández de la Calleja), 149 (“los del Viejo”), 158 (Juan Sánchez), 161 (herederos de Alonso Fernández Buenadicha), 168 (Toribio Jiménez), 177 (herederos de Alonso Fernández Buenadicha) (pp. 200-203, 205, 211, 222, 226-229 y 232).

186 "La qual tierra es en la Çepeda los Mosquitos desde la pinarada de rromeras fasta el camino que va por çima de la çerrada de los herederos de Juan Martín de Navadijos, que Dios aya", Ibidem, 128 (p. 223).

187 Ibidem, doc. 1, 72 (p. 211), vid. supra. 
en la proliferación de nuevos; la repetida alusión al reagrupamiento de la heredad es testimonio de esta evolución ${ }^{188}$.

La entrega de pequeñas parcelas al concejo para mantener terrenos usurpados pudo representar, en principio, una forma de compensar daños ya consumados, tal como ocurre tras la pesquisa de 1458: según se observa en el cuaderno de Navarredonda, dos de los sujetos que están en falta mantienen sus explotaciones ilegales cediendo tierras al concejo rural. Esta pesquisa, la más importante para el concejo de Piedrahíta por el tiempo y costo que supone, afecta cinco tierras que recuperan su condición concejil ${ }^{189}$, diez parcelas labradas en los comunales ${ }^{190}$, dos linares creados en $\operatorname{prados}^{191}$ y dos cerrados extendidos sobre tierras concejiles ${ }^{192}$. Uno de los linares vuelve a constituirse mediante la entrega de tierras al año siguiente ${ }^{193}$, y en cuanto a los cerrados ampliados, su titular es el sexmero Alonso Martínez de Barajas, que legaliza sus emprendimientos unos años más tarde negociando con el concejo rural ${ }^{194}$. La pesquisa, en suma, además de expresar un acontecimiento excepcional, afecta centralmente tierras labradas en los comunales antes que cercamientos de heredades, los cuales se consolidan poco tiempo después.

Por otro lado, el mismo tipo de arreglo se reitera a lo largo de cincuenta años, y asistimos hacia el final del período a la formación de nuevos cerrados. Esta evidencia demuestra que la cesión de tierras al concejo es el mecanismo habitual para amalgamar posesiones y constituir o ampliar bloques cercados, lo cual indica el avance de la elite aldeana antes que el intento por parte del concejo rural de moderar sus prácticas acumulativas. Vale la pena entonces detallar la negociación de un cerrado a finales del periodo comprendido en el cuaderno de Navarredonda.

Este caso es el único que se describe extensamente en el cuaderno, lo cual se explica por ser también el único que se trata en una reunión abierta de concejo. La reunión se celebra en 1483 a raíz de una grave falta que cometió un vecino: tras haber acordado con el concejo en 1482 la entrega de una tierra para obtener un cerrado recurre al

${ }_{188}$ Por ejemplo, Alonso Fernández de la Calleja obtiene por trueque con el concejo "un girón arrimado al su linar", Ibidem, doc. 1, 110 (p. 219); Juan García de los Palillos obtiene una tierra "para alargar un linar", Ibidem, doc. 1, 202 (p. 236); Alonso Fernández Bravo un pradejón "entre una su tierra", Ibidem, doc. 1, 143 (p. 226); Fernán Sánchez de Barajas un girón “cabe un su prado”, Ibidem, doc. 1, 160 (p. 229); Diego Sánchez obtiene una tierra "que alinda con una tierra suya", Ibidem, doc. 1, 107 (p. 218); Toribio Jiménez obtiene un prado "cabe otro suyo (...) para que lo pueda çerrar con lo suyo", Ibidem, doc. 1, 168 (p. 230); Alonso Sánchez de la Iglesia consigue "un pedaço cabe el su linar (...) que saque la pared afuera e lo çierre con el linar", Ibidem, doc. 1, 106 (p. 218), etc.

189 Ibidem, doc. 1, 28, 29, 20, 31, 32 (p. 204).

190 Ibidem, doc. 1, 35, 36, 37, 38, 39, 40, 41, 43, 44, 45 (pp. 204-205).

191 Ibidem, doc. 1, 33, 34 (p. 204).

192 "Otrosý libraron en este año de LVIII ha Alonso Martínez de Ba[ra]jas que en el çerrado que él tyene en Los Arroyos que dexe lo que tiene de conçejo e que eche la pared por lo suyo. Otrosý libraron más al dicho Alonso Martínez que dé dos tanto de lo que tiene tomado en el cerrado del Rrebanal donde pertenece al concejo", Ibidem, doc. 1, 42 (p. 205).

${ }^{193}$ En 1458 "huvo pleyto el conçejo con Per Alfonso sobre un linar quél fazía en la Defesa de concejo a la huerta en un su prado; e quedó librado que non faga linar nin le rrompa, salvo que le posee por suyo por prado commo siempre lo poseó", Ibidem, doc. 1, 34 (p. 204); en 1459 "dio Pero Alonso al conçejo un pedaçuelo de tierra (...) por que le dexen çerrar un linar que çierra en la huerta", Ibidem, doc. 1, 47 (p. 205).

194 Ibidem, doc. 1, 77 (p. 212). 
alcalde de Piedrahíta para recuperar la tierra cedida al concejo. Este es el hecho que acaba dando lugar a una reunión abierta:

e syn lo fazer saber al conçejo fuése a Piedrafita e truxo carta del alcalde que le tornasen lo suyo e que lo que le davan que lo entendía de fazer suyo. Y entonçe el conçejo, mirando sus ordenanças, fallaron que tenía pena de sesenta maravedís por aver ydo su parte a demandar la dicha carta, e mandaron taner la canpana e fuéronlos abener ${ }^{195}$.

El vecino en cuestión, Juan Sánchez, es pariente de oficiales. Su hermano fue jurado y procurador ${ }^{196}$ y sus cuñados son miembros destacados del concejo; uno fue sexmero $^{197}$, y otros dos han sido alcaldes: se trata de la familia de los Fernández Buenadicha, a la cual pertenece el sacristán de la aldea, que relata el caso. Este relato es el registro de la reunión abierta del concejo de 1483 y de los sucesos acaecidos en 1482, que no fueron anotados en su momento y que ahora salen a la luz. Según el relato del sacristán, en 1482 Juan Sánchez había cedido al concejo una tierra a cambio de un prado lindero a otro suyo y el permiso para cercar el bloque, que incluía otro terreno de las inmediaciones, al parecer de condición concejil; para evitar un pleito, este vecino habría propuesto ceder más tierra ${ }^{198}$, el concejo le habría exigido ceder un poco más y Juan Sánchez, aunque en desacuerdo, habría aceptado ${ }^{199}$. El problema surge al año siguiente, cuando Juan Sánchez reclama la devolución de lo que cedió al concejo avalado por una carta del alcalde de Piedrahíta -lo que también demuestra la complicidad de las autoridades urbanas con los sectores acomodados aldeanos. Aquí es cuando el concejo rural, en resguardo de su autonomía, le impone la multa por haber llevado el caso a una instancia superior incumpliendo las ordenanzas locales. El desafortunado intento de recurrir a un contacto en Piedrahíta desconociendo a las autoridades aldeanas lleva a que el acuerdo previo tome publicidad, lo que explica su descripción detallada en el cuaderno. Finalmente los prestigiosos parientes de este

\footnotetext{
${ }^{195}$ Ibidem, doc. 1, 158 (p. 228).

${ }_{196}$ Ibidem, doc. 1, 178 (p. 232), 195 (p. 235), 131 (p. 224).

197 Alonso Fernández Buenadicha el mozo actúa como sexmero en 1447, Luis LóPEz, Documentación medieval de Piedrahita, vol. I, doc. 132.

198 "Este dicho día, estando el conçejo ayuntado a canpana rrepicada según lo an de uso e de costunbre, por quanto en el año pasado de ochenta e dos años el conçejo avía dado a Juan Sánchez, hijo de Bartolomé Sánchez, un poco de prado en la Lastrilleja abuelta de otro suyo y el dicho Juan Sánchez dio al conçejo un pedaçuelo de tierra que él tenía (...) que el conçejo le diese a él lugar que aquello que le dava que lo podiese çerrar a buelta de lo suyo, por quanto estaba un pradejón entre aquella tierra e prado de la Lastrilleja que el dicho Juan Sánchez quería çerrar; y el dicho Juan Sánchez dezía que aquel pradejón era suyo e lo podía e quería çerrar con la dicha eredad; y el concejo dezía que non era suyo nin je lo consentirían çerrar (...) e por quitarse de pleyto el dicho Juan Sánchez dixo que quería dar al conçejo otro tanto o más, lo que buenos omes viesen e mandasen (...) a lo qual el conçejo dixo que le plazía”, Del Ser Qujuano, Documentación Medieval en Archivos Municipales Abulenses. Documentación Medieval del Archivo Municipal de Navarredonda de Gredos, doc. 1, 158 (pp. 227-228).

199 "Y, ellos ydo ansý a ver lo que el dicho Juan Sánchez dava al conçejo, a los que con él fueron fazíaseles poco e señalaron por más arriba de lo que el dicho Juan Sánchez les dava y el dicho Juan Sánchez non consintió en ello. E luego los dichos buenos onbres le dixeron que, sý ansý non quería, que se quedase con lo suyo e dexase lo de conçejo abierto (...) e veniéndose ansý desconçertados (...) el dicho Juan Sánchez dixo a los otros que tornasen e señalasen por donde quejesen (...) y ellos bolvieron allí e le dixeron que oviese por çierto que de lo que avían señalado que non le tomarían más un pelo nin le quitarían otro", Ibidem, doc. 1, 158 (p. 228).
} 
vecino aseguran el acuerdo y el concejo, que ahora estaría expresando una reunión ampliada, por la mediación de estos personajes destacados olvida la multa y convalida el arreglo por el cual un particular obtiene un cerrado cediendo tierras al concejo rural $^{200}$.

Este desenlace pone en evidencia el dominio incontestado de los notables locales, por cuyo ascendiente los que están "ayuntados a canpana rrepicada" aceptan un cercamiento. También demuestra la importancia que otorgan los dirigentes aldeanos al acuerdo interno, cuya base es el reconocimiento del concejo rural como autoridad suficiente, es decir, que puede prescindir de poderes superiores para gobernar. Puesto que éste también es el criterio práctico de las autoridades urbanas, la autonomía de la comunidad depende en gran parte del disciplinamiento de sus miembros individuales, a lo cual apuntan las ordenanzas en cuestión -vigentes por otro lado durante más de treinta años.

La proliferación de cerrados, aun cuando éstos se conformen mediante la entrega de tierras al concejo, afecta la reproducción de los sectores más débiles, que pierden el acceso al pastoreo en las tierras que se sustraen del régimen de campo abierto y en terrenos comunales. Las parcelas que obtiene el concejo rural, por otro lado, lejos de consolidarse como bienes concejiles aldeanos sirven a las estrategias de los que intentan amalgamar posesiones, lo cual favorece una dinámica orientada a la privatización de la tenencia. Esta dinámica supone la libertad de fragmentar y enajenar tierras, lo que confirma la centralidad de los contenidos específicos del dominio político sobre la persona en el análisis de las condiciones de desarrollo de procesos acumulativos ${ }^{201}$.

Se trata, por último, de una dinámica propia de las aldeas: si bien se constata la existencia de cerrados en el término de la villa de Piedrahíta ${ }^{202}$ se deduce también que este espacio político, sujeto naturalmente a mayor supervisión, resulta menos propicio para el desarrollo de este tipo de prácticas. Un ejemplo de ello es la importancia que parecen dar las autoridades urbanas a ciertos cercados realizados por un cura, sobre los cuales el concejo traba embargo en 1475 con la asistencia de los regidores, el alcalde, el procurador, el escribano, un escudero, cuatro hombres buenos y "otros de la villa"203, un despliegue de personal político que no se observa en los escasos operativos que se realizan en las aldeas.

200 "E luego Alonso Ferrández Buenadicha e Juan Ferrández e Alonso Ferrández, cuñados del dicho Juan Sánchez, fueron a su casa e rriñeron con él e le acusaron farto, diziéndole que traya más camino e que avría de conplir con el conçejo como primero avía quedado (...) y él, ansý vençido, fuéronse todos juntamente donde el conçejo estava abeniéndole la dicha pena; y, ellos fecha su rrelaçión, el conçejo por onrra de aquellos buenos onbres que yvan con él les plugo de le rrelevar la dicha pena (...) e de allí quedó con el conçejo que goze de lo que él da en la cañadilla y él que çierre el dicho pradejón a buelta de lo suyo e que nunca más yrá nin verná contra esta demanda", Ibidem, doc. 1, 158 (p. 228).

201 Este problema fue advertido por Kosminsky, que detectó en Inglaterra procesos de acumulación tempranos entre la población tributaria de freeholders, sujeta a menores restricciones que el campesino villein, Kosminsky, Studies in the agrarian history of England. Hitton, "Razones de la desigualdad", p. 53, observa también un mayor potencial para la acumulación entre campesinos de condición libre (cuya situación se correspondería con la de los pecheros de concejos castellanos).

202 Luis López, Las finanzas de un concejo castellano, vol. III, p. 107; LuIs López, Documentación medieval de Piedrahita, vol. III, doc. 25, 53, 56 y 78.

203 "Fueron los señores Pedro de Vargas e Pedro de Várzena e el alcalde, Pedro Fernández Rresbala, e Gonçalo Gonçalez, escrivano, e el procurador e quatro onbres buenos, labradores, a ver el çerrado que çierró el 
El problema de la multiplicación de cerrados es objeto de la normativa de Piedrahíta a fines del siglo XV. En respuesta a una petición del concejo se concede en 1488 que no se penalicen daños ya consumados, a condición de que en adelante se envíen una o dos personas al año a controlar las aldeas, dado que el problema se atribuye al "aver dexado tanto tiempo denviar a visitar e requerir la tierra" 204 , lo que confirma que el perfil de gestión descrito facilita estos emprendimientos. Once años después una petición de los procuradores deja ver qué intereses defienden los representantes de la tierra: en vista de ciertas leyes del reino relativas al problema los procuradores solicitan que se respete aquello de no penalizar a los que ya han realizado cercamientos argumentando que "la pérdida de los muchos edefiçios sería muy grande", y que de estos espacios también se beneficia "su señoría", quien "con condiçión de un çerrado está en la tierra e viene a ella con sus ganados" 205 . Se deduce que los procuradores y sexmeros, que en Navarredonda detentan cerrados, actúan amparados no sólo por el concejo aldeano y el concejo urbano sino también por el señor, con quien comparten intereses ganaderos y espacios apropiados.

En una recopilación de ordenanzas de 1499 se describe el daño que han causado los cerrados: han reducido los pastos de las aldeas y han disminuido el sustento ganadero de los vecinos, lo cual confirma el efecto de la apropiación del espacio sobre la reproducción de una parte de la población ${ }^{206}$. La difusión de cerrados, por último, habría sido un fenómeno generalizado en el ámbito de Piedrahíta, según las ordenanzas mencionadas antes, y se habría desarrollado también en los concejos vecinos del señorío de Valdecornej $\mathrm{a}^{207}$. Fuera de Navarredonda lo hemos verificado en el concejo rural de La Garganta del Villar, en el de Santiago y en el de Hoyorredondo (en este caso propiedad de un regidor, lo cual confirma la confluencia de las prácticas de la elite aldeana y la oligarquía urbana $)^{208}$.

cura, e Alonso Tamayo e otros de la villa, e se puso embargo en los çierros", Álvarez Fernández, Las finanzas de un concejo castellano, vol. VII, p. 61.

${ }^{204}$ Luis LóPEz, Colección Documental del Archivo Municipal de Piedrahíta, doc. 39 (1488).

205 "Suplicar a vuestra señoría y pedille, por merçed, que se guarde, porque sy de otra manera se fiziese, su señoría sería muy deservido e sus vasallos muy danyficados, porque con condiçión de un çerrado está en la tierra e viene a ella con sus ganados; por manera que, si agora se oviese de derrocar, conforme a las leyes del reyno, su señoría, como dicho es, sería muy deservido e la pérdida de los muchos edefiçios sería muy grande, en mucha cantidad", Ibidem, doc. 61 (1499), p. 120.

206 "Por quanto segund la multiplicaçión que Nuestro Señor ha dado en las gentes e ganados de la dicha villa e tierra, e los muchos hedefiçios de huertas e prados e montes que se han çerrado de cada día en los heredamientos de la dicha villa e tierra, a cabsa de lo qual se ha estrechado e estrecha mucho la tierra e pastos e comunes della, donde redunda e redundaría, para adelante, mucho daño e disminuçión de los dichos ganados, que es lo más principal de que los vezinos e moradores de la dicha villa e tierra se sostienen e mantienen, por tanto, ninguno nin algunos sean osados de çerrar ninguna çerradura de nuevo en ninguna heredad que tenga, syn liçencia e expreso mandamiento del duque, nuestro señor, o del concejo, justiçia e regidores de la dicha villa", Ibidem, doc. 65, p. 134.

${ }^{207}$ La expansión de cerrados se habría producido también en el concejo vecino de El Barco de Ávila, DE Santos CAnAlejo, "Piedrahíta", p. 1169. La autora, sin embargo, considera en otro trabajo que los cercamientos de prados concejiles y privados en Valdecorneja habrían estado sujetos a regulación y no habrían sido un obstáculo para el aprovechamiento comunal, De SANTOS CANaLejo, "El aprovechamiento de términos", p. 379.

${ }^{208}$ Vid. supra. En relación a Hoyorredondo se menciona en un deslinde "el çerrado de Fernand Blázquez", regidor de Piedrahíta, Luis LóPez, Documentación medieval de Piedrahíta, vol. III, doc. 87. 


\section{CONCLUSIONES}

La gestión del espacio jurisdiccional, delegada en el concejo urbano, resulta efectiva en la medida en que se apoya en los canales organizativos basados en la participación de pecheros, cuyo protagonismo, por otro lado, es funcional al perfil del sector gobernante, desvinculado en términos prácticos del control del ámbito rural. Este aspecto de la actuación política de las autoridades urbanas -que también se explica por la familiaridad del sector con las prácticas que debe reprimir- redunda en una mayor libertad de acción en las aldeas, cuyo alto nivel de autonomía hemos comprobado. Los historiadores han asociado este rasgo a la evolución del feudalismo; en nuestro caso la autonomía relativa de los concejos rurales se deriva de una forma específica de gestión, susceptible de oponerse a modalidades patrimonialistas en las que la administración se lleva a cabo mediante clientes y allegados del señor.

El autogobierno aldeano, una aspiración de la elite campesina, se manifiesta en el dictado de ordenanzas independientes, en la regulación interna del conflicto aldeano e interaldeano y en la capacidad de disposición sobre bienes particulares y concejiles, que posibilita alteraciones en los usos agrarios y favorece la tendencia a la privatización de pastos. Esta orientación, que tiene su punto de partida en los privilegios otorgados a los líderes aldeanos cuando se constituye institucionalmente la comunidad, expresa el perfil de las autoridades rurales en la Baja Edad Media. El protagonismo de la elite aldeana y la constante afirmación de la autonomía del concejo rural son aspectos consistentes con un criterio de gestión que descansa ampliamente en sectores pecheros y que privilegia la percepción de cierto volumen general de renta y el resguardo de la jurisdicción por sobre el control interno.

\section{BIBLIOGRAFÍA}

Álvarez Fernández, María, Las finanzas de un concejo castellano: Piedrahita, siglos XV-XVI. Estudio y documentos, vol. VII (1474-1480), Ávila, 2011.

Asenjo GonzÁlez, María, Segovia. La ciudad y su tierra a fines del medioevo, Segovia, 1986.

Astarita, Carlos, "Representación política de los tributarios y lucha de clases en los concejos medievales de Castilla", Studia Historica. Historia Medieval, 15 (1997), pp. 139-169.

Astarita, Carlos, “¿Tuvo conciencia de clase el campesino medieval?”, Edad Media, 3 (2000), pp. 89-113.

Astarita, Carlos, Revolución en el burgo, 4 vols., inédito.

Beltrán SuÁrez, Soledad, Las finanzas de un concejo castellano: Piedrahíta, siglos XV-XVI. Estudio y documentos, vol. VI (1467-1473), Ávila, 2011.

Bourin, Monique, "Peasant Elites and Village Communities in the South of France, 1250-1350", Past and Present, 195, 2 (2007), pp. 101-114. 
Clemente Ramos, Julián, "Valdetorres, de dehesa a aldea (1409-1510). Poblamiento, conflicto y poder en la tierra de Medellín", Studia Historica. Historia Medieval, 20-21 (2002-2003), pp. 47-72.

Clemente Ramos, Julián, "Ordenanzas y conflictividad intracampesina en Mengabril (1548)", en María Isabel del Val Valdivieso y Pascual Martínez Sopena (coords.), Castilla y el mundo feudal. Homenaje al profesor Julio Valdeón, vol. III, Valladolid, 2009, pp. 241-247.

Clemente Ramos, Julián, "La explotación económica del Campo Arañuelo y la economía rural de la tierra de Plasencia a mediados del siglo XV", Anuario de Estudios Medievales, 39/1 (2009), pp. 245-274.

Clemente Ramos, Julián y Rodríguez Grajera, Alfonso, "Plasencia y su tierra en el tránsito de la Edad Media a la Moderna. Un estudio de sus ordenanzas (14691593)", Revista de Estudios Extremeños, vol. 63, 2 (2007), pp. 725-788.

Colombo, Octavio, "Producción campesina y poder concejil en Piedrahíta. La ordenanza sobre la madera de 1405", Actas y Comunicaciones del Instituto de Historia Antigua y Medieval, vol. 9, 2013.

DA GRACA, Laura, "Intercambio de tierras y otras prácticas agrarias en concejos castellanos (siglo XV)", Anales de la Universidad de Alicante. Historia Medieval, 14 (2003-2006), pp. 111-144.

Da Graca, Laura, Poder político y dinámica feudal. Procesos de diferenciación social en distintas formas señoriales (siglos XIV-XVI), Valladolid, 2009.

De Santos Canalejo, Elisa, "Piedrahíta, su Comunidad de Villa y Tierra y los duques de Alba en el siglo XV", En la España Medieval, 5 (1986), pp. 1141-1174.

De Santos Canalejo, Elisa, "El aprovechamiento de términos a fines de la Edad Media castellana en las comunidades de villa y tierra serranas: Plasencia, Béjar, Valdecorneja, Arenas, Mombeltrán y Candeleda", Anuario de Estudios Medievales, 20 (1990), pp. 374-387.

Del Ser Quijano, Gregorio, Documentación Medieval en Archivos Municipales Abulenses (Aldeavieja, Avellaneda, Bonilla de la Sierra, Burgohondo, Hoyos del Espino, Madrigal de las Altas Torres, Navarredonda de Gredos, Riofrio, Santa Cruz de Pinares y El Tiemblo), Ávila, 1998.

Del Ser Quijano, Gregorio, Documentación medieval de Piedrahita: estudio, edición crítica e índices, vol. II (1448-1460), Ávila, 2010.

Del Ser Quijano, Gregorio, Las finanzas de un concejo castellano: Piedrahita, siglos XV-XVI. Estudio y documentos, vol. II (1434-1444), Ávila, 2011.

Del Ser Quijano, Gregorio, "Fiscalidad real y señorial en el señorío de Valdecorneja a mediados del siglo XV", en Pablo de la Cruz Díaz, Fernando Luis Corral e Iñaki Martín Viso (eds.), El historiador y la sociedad. Homenaje al Profesor José $M^{a}$. Mínguez, Salamanca, 2013, pp. 246-259.

Diago Hernando, Máximo, "Introducción a la historia institucional del concejo de Soria en la Baja Edad Media, En la España medieval, 11 (1988), pp. 23-43. 
Diago Hernando, Máximo, "Cambios políticos e institucionales en Aranda de Duero desde el acceso al trono de los Reyes Católicos hasta la revuelta comunera", Edad Media, 9 (2008), pp. 299-342.

Dobson, Richard Barry (ed.), The Peasants'Revolt of 1381, Londres, 1970.

DYER, Christopher, Lords and peasants in a changing society. The estates of the bishopric of Worcester, 680-1540, Cambridge, 1980.

DYer, Christopher, “A Redistribution of Incomes in Fifteenth-Century England?", en Rodney Hilton (ed.), Peasants, Knights and Heretics. Studies on Medieval English Social History, Cambridge, 1981, pp. 192-215.

Dyer, Christopher, "The English Medieval Village Community and its Decline", Journal of British Studies, 33 (1994), pp. 407-429.

Dyer, Christopher, "Power and Conflict in the Medieval English Village", en Everyday Life in Medieval England, Londres, 1994.

DYer, Christopher, "The Ineffectiveness of Lordship in England", Past and Present, 195, 2 (2007), pp. 69-86.

García Garcimartín, Hugo Joaquín, Articulación jurisdiccional y dinámica socioeconómica de un espacio natural: la cuenca del Alberche (siglos XII-XV), tesis doctoral, Madrid, 2002.

HiLton, Rodney, Siervos liberados. Los movimientos campesinos medievales y el levantamiento inglés de 1381, Madrid, 1978.

HiLton, Rodney, "Razones de la desigualdad entre los campesinos medievales", en Conflicto de clases y crisis del feudalismo, Barcelona, 1988.

JARA Fuente, José Antonio, "Sobre el concejo cerrado. Asamblearismo y participación política en las ciudades castellanas de la Baja Edad Media (conflictos inter o intra-clase), Studia Historica. Historia Medieval, 17 (1999), pp. 113-136.

Kosminsky, Eugene A. Studies in the agrarian history of England in the thirteenth century, Oxford, 1956.

Luis López, Carmelo, Colección Documental del Archivo Municipal de Piedrahita (1372-1549), Ávila, 1987.

Luis López, Carmelo, La Comunidad de villa y tierra de Piedrahita en el tránsito de la Edad Media a la Moderna, Ávila, 1987.

LuIs LóPEz, Carmelo, Documentación medieval de Piedrahíta: estudio, edición crítica e índices, vol. I (1372-1447), Ávila, 2007.

LuIs LóPEZ, Carmelo, Las finanzas de un concejo castellano: Piedrahita, siglos XVXVI. Estudio y documentos, vol. III (1445-1452), Ávila, 2011.

Luis LóPez, Carmelo, Documentación medieval de Piedrahita: estudio, edición crítica e índices, vol. III (1461-1465), Ávila, 2012.

Martín Cea, Juan Carlos y Bonachía, Juan Antonio, "Oligarquías y poderes concejiles en la Castilla bajomedieval. Balance y perspectivas", Revista d'História Medieval, 9 (1998), pp. 17-40. 
Monsalvo Antón, José María, El sistema político concejil. El ejemplo del señorío medieval de Alba de Tormes y su concejo de villa y tierra, Salamanca, 1988.

Monsalvo Antón, José María, "La participación política de los pecheros en los municipios castellanos de la Baja Edad Media. Aspectos organizativos", Studia Historica. Historia Medieval, 7 (1989), pp. 37-93.

Monsalvo Antón, José María, "Transformaciones sociales y relaciones de poder en los concejos de frontera, siglos XI-XIII. Aldeanos, vecinos y caballeros ante las instituciones municipales", en Reyna Pastor (comp.), Relaciones de poder, de producción y parentesco en la Edad Media. Aproximación a su estudio, Madrid, 1990, pp. 107-170.

Monsalvo Antón, José María, "Paisaje agrario, régimen de aprovechamientos y cambio de propiedad en una aldea de la tierra de Avila durante el siglo XV. La creación del término redondo de Zapardiel de Serrezuela", Cuadernos Abulenses, 17 (1992), pp. 11-110.

Monsalvo AnTón, José María, “'Ayuntados a concejo’. Acerca del componente comunitario en los poderes locales castellano-leoneses durante la Edad Media", en Flocel Sabaté i Curull y Joan Farré (coord.), El poder a l'Edat Mitjana : Reunió cientifica, VIII Curs d'Estiu Comtat d'Urgell (Balaguer, 9, 10 i 11 de juliol de 2003), 2004.

Monsalvo Antón, José María, Comunalismo concejil abulense. Paisajes agrarios, conflictos y percepciones del espacio rural en la Tierra de Ávila y otros concejos medievales, Diputación provincial de Ávila, 2010.

Monsalvo Antón, José María, "Costumbres y comunales en la tierra medieval de Ávila (observaciones sobre los ámbitos de pastoreo y los argumentos rurales en los conflictos de términos", en Comunalismo concejil abulense. Paisajes agrarios, conflictos y percepciones del espacio rural en la Tierra de Ávila y otros concejos medievales, Diputación provincial de Ávila, 2010, pp. 251-319.

Monsalvo Antón, José María, "Raíces sociales de los valores estamentales concejiles: la construcción de las mentalidades y culturas rurales de caballeros y pecheros", en Comunalismo concejil abulense. Paisajes agrarios, conflictos y percepciones del espacio rural en la Tierra de Ávila y otros concejos medievales, Diputación provincial de Ávila, 2010, pp. 359-421.

Monsalvo AnTón, José María, "Espacios de pastoreo de la tierra de Ávila. Algunas consideraciones sobre tipos y usos de los paisajes ganaderos bajomedievales", en Comunalismo concejil abulense. Paisajes agrarios, conflictos y percepciones del espacio rural en la Tierra de Ávila y otros concejos medievales, Diputación provincial de Ávila, 2010, pp. 191-250.

Monsalvo Antón, José María, Las finanzas de un concejo castellano: Piedrahita, siglos XV-XVI. Estudio y documentos, vol. IV (1453-1461), Ávila, 2011.

Monsalvo AnTón, José María, "Ideario sociopolítico y valores estamentales de los pecheros abulenses y salmantinos (ss. XIII-XV)", Hispania, LXXI, 238 (2011), pp. 325-362.

Monsalvo Antón, José María, “Torres, tierras, linajes. Mentalidad social de los caba- 
lleros urbanos y de la elite dirigente en la Salamanca medieval (siglos XIII-XV)", en José María Monsalvo Antón (ed.), Sociedades urbanas y culturas políticas en la Baja Edad Media castellana, Salamanca, 2013, pp. 165-230.

Moreno NúÑEz, José Ignacio, Ávila y su tierra en la Baja Edad Media (Siglos XIII$X V)$, Junta de Castilla y León, 1992.

Morsel, Joseph, La aristocracia medieval. El dominio social en Occidente (siglos $V-X V)$, Valencia, 2008.

Olmos Herguedas, Emilio, La comunidad de villa y tierra de Cuéllar a fines de la Edad Media. Poder político concejil, ordenanzas municipales y regulación de la actividad económica, Valladolid, 1998.

SÁnchez Benito, José María, "El poder en una pequeña ciudad castellana: El ejemplo de Huete en el siglo XV", En la España Medieval, 25 (2002), pp. 177-212.

SÁnchez Benito, José María, "Estructura social de un pueblo de Castilla en época de los Reyes Católicos: Fuentes, aldea de Cuenca", En la España Medieval, 31 (2008), pp. 97-122.

TAWNEY, Richard Henry, The agrarian problem in the sixteenth century, London, 1912.

Tena García, María Soledad, Las finanzas de un concejo castellano: Piedrahita, siglos XV-XVI. Estudio y documentos, vol. V (1462-1466), Ávila, 2011.

Whittle, Jane, "Peasant Politics and Class Consciusness: the Norfolk Rebellions of 1381 and 1549 Compared", Past and Present, 195, 2 (2007), pp. 233-347.

Wickham, Chris, Community and Clientele in Twelfth-Century Tuscany. The origins of the rural commune in the plain of Lucca, Oxford, 1998.

Wickнam, Chris, "Conclusions", Past and Present, 195, 2 (2007), pp. 304-316. 